\title{
85 Years of Catalysis at Firmenich
}

\author{
Lionel Saudan*
}

Dedicated to Valentin Rautenstrauch, to celebrate the $22^{\text {nd }}$ anniversary of the precious metal homogeneous catalytic process towards Paradisone ${ }^{\circledR}$

\begin{abstract}
This review relates 85 years of catalysis performed at Firmenich. A special emphasis is shown on how the industry has always focussed on improving the environmental profile of the perfumery ingredients produced and on making them more sustainable. In particular through the application of one of the key principles of Green Chemistry, no. 9, which concerns catalysis. These trends have of course impacted the choice and the need for industrial processes that generate less waste, use less solvent and minimize energy requirements. This review has been organized around key transformations used at Firmenich, and a comparison between stoichiometric and catalytic approaches for some important perfumery ingredients is presented.
\end{abstract}

Keywords: Catalysis · Flavour \& Fragrance · Green chemistry

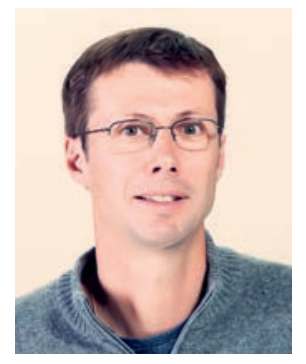

Dr. Lionel Saudan is a Principal Scientist at the corporate R\&D Division of Firmenich S.A. in Geneva (Switzerland). He joined the company in 2000, after a two-year post-doctoral stay in the group of Professor J. M. Tour, working on the synthesis of a new 'nanocar' at the University of South Carolina and at Rice University (Texas). He obtained his BSc and $\mathrm{PhD}$ (1998) from the University of Geneva under the supervision of Professor E. P. Kündig working on the asymmetric synthesis of new chiral amines. His current research topics are in the field of homogeneous catalyzed hydrogenation reactions in the context of the development of new perfumery ingredients.

\section{Introduction}

Nowadays, there is a tremendous push within the Fragrance \& Flavour $(\mathrm{F} \& \mathrm{~F})$ industry towards the development of sustainable ingredients through the application of the Green Chemistry Principles. ${ }^{[1]}$ In particular through the application of one of the key principles, no. 9, which concerns catalysis. Firmenich has been a pioneer in the field with its long-standing legacy in the field of catalysis. Indeed, the first catalytic process dates back to 1935 , and concerned patents on gas-phase formation of macrocyclic lactones using a solid support. ${ }^{[2]}$ Firmenich has always focussed on improving the environmental profile of the perfumery ingredients produced ${ }^{[3]}$ and on making them more sustainable. ${ }^{[4]}$ These trends have of course impacted the choice and the need for industrial processes that generate less waste, use less solvent and minimize energy requirements. Catalytic processes used in the F\&F industry have already been reviewed in the past, citing examples of research performed at Firmenich. ${ }^{[5]}$ Since the 1950s, chemical processes at Firmenich have relied on a variety of metalbased catalysts (Fig. 1). This review has been organized around key transformations used at Firmenich and a comparison between stoichiometric and catalytic approaches for some important perfumery ingredients is presented.

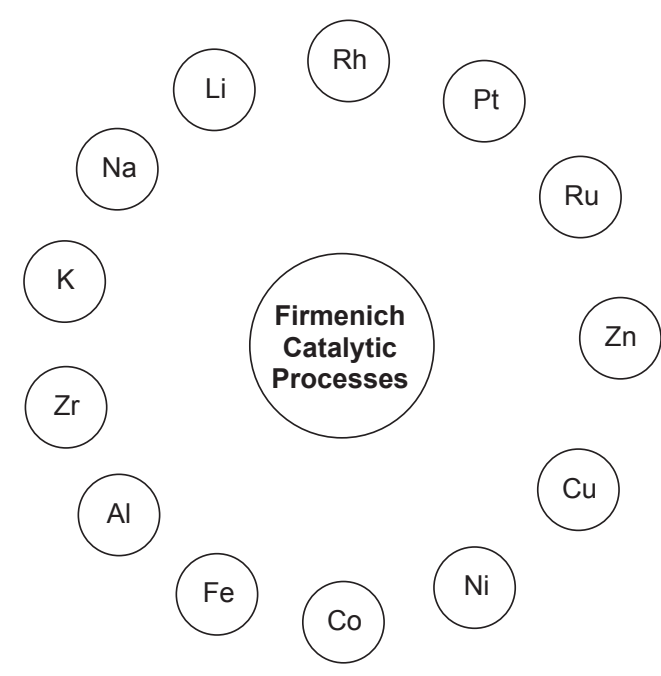

Fig. 1. Overview of metals used in catalytic processes at Firmenich for the synthesis of perfumery ingredients.

\section{Metal-catalyzed Cyclization}

In this first section, we describe the efforts made over the years towards continuously improving the synthesis of cyclic perfumery ingredients discovered in house, by reducing the number of stoichiometric chemical steps and replacing them by catalytic processes.

\subsection{Pd-catalyzed Cycloisomerization ${ }^{[6]}$}

Palladium-catalyzed cycloisomerizations kicked off Firmenich's journey in using metal catalysis for the synthesis of perfumery ingredients. As reported in 1984 by Rautenstrauch, ${ }^{6}{ }^{6}$ treatment of dehydrolinalyl acetate (1) with a $\mathrm{Pd}(\mathrm{II})$ catalyst did not give the expected rearranged allenic isomer 2 , but instead the cyclization product 3 which was obtained in low yield (10-40\%) (Scheme 1). This was similar to what had been previously reported in 1976 by Ohloff and Strickler using $\mathrm{ZnCl}_{2}$ as catalyst. ${ }^{[7]}$ Rautenstrauch hypothesized that chelation of the double and the triple bond should facilitate the cyclization, and it should be stronger for $n=0$ rather than $n=2$ as in $\mathbf{1}$ (Scheme 1). This turned out to be correct, and led to a new synthesis of cylopentenones 
Scheme 1. Pd-catalyzed cycloisomerization (Rautenstrauch rearrangement).

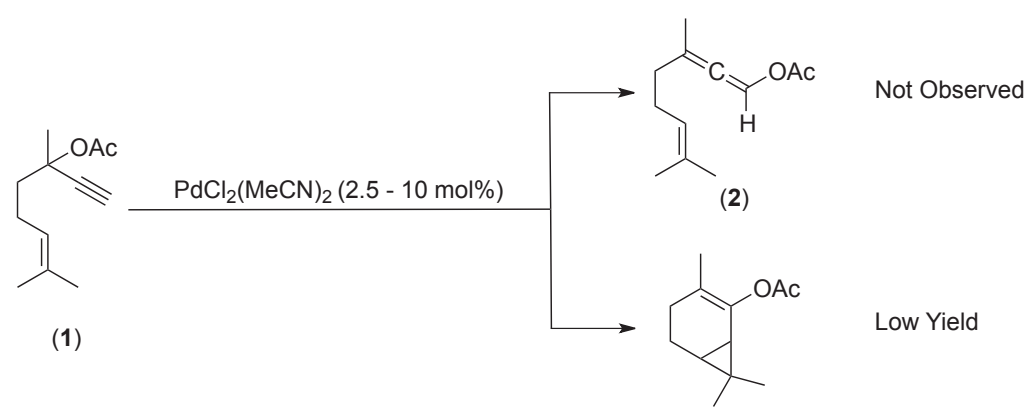

(3)<smiles>[R]C(=C)CC([R20])(C#C)C#C</smiles>

(4)

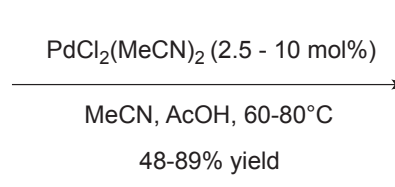

$48-89 \%$ yield<smiles>[R]C1=C([R])C(=O)CC1</smiles>

(5)

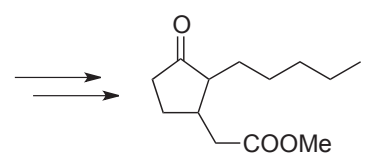

(6)
Hedione ${ }^{\odot}$ $\mathbf{5}$, important starting materials for perfumery ingredients such as Hedione $^{\odot}(6)^{[8]}$ or Exaltone ${ }^{\odot}$ (7). ${ }^{[9]}$ ate bicyclopentadecenone $\mathbf{8}$ was synthesized in two steps from cyclododecanone $\mathbf{9}$ as shown in Scheme 2 using a large amount of polyphosphoric acid.9a] Therefore, the new catalytic version, based on a Pd-catalyzed pentaannulation reaction, led to a sevenfold reduction of the $E$ factor of the cyclization step ( $E$ factor 7 vs. 67).

At that time, only one other suitable metal species, $\mathrm{Pt}(\mathrm{II})$, was successfully tried, despite a lower reactivity. This reaction was later further exemplified by Toste using gold catalysis. ${ }^{[10]}$

\subsection{Pt, Au and Cu-catalyzed Cycloisomerization ${ }^{[11-13]}$}

Some 20 years after the first Pd(II)-catalyzed cycloisomerization of enyne acetate (4), Fehr reinvestigated the intramolecular cyclopropanation that had failed for dehydrolinalyl acetate (1) as shown above. This proved to be quite successful and led to a new stereoselective synthesis of (-)-Cubebol (10), ${ }^{[11,14]}$ a naturally occurring sesquiterpene with a cooling, refreshing taste, used in a range of products from chewing gum, sorbets and drinks. In order to prepare enyne carboxylate 11, the authors started from tetrahydrocarvone, a readily available starting material. The cycloisomerization of enyne
In the previous synthesis of Exaltone ${ }^{\odot}(7)$, the key intermedi- carboxylate $\mathbf{1 1}$ was then performed with a variety of catalysts, and the use of $\mathrm{Au}(\mathrm{I})$ and $\mathrm{Pt}(\mathrm{II})$-catalysts proved to be successful,,[11] but more interestingly $\mathrm{Cu}(\mathrm{I})$-based catalysts were found to be as efficient as $\mathrm{Au}(\mathrm{I})$ - and $\mathrm{Pt}(\mathrm{II})$-catalysts as shown in Scheme 3.[15]

Later on it was found that a second fragmentation path of the enynol 12 could be attained via a $\mathrm{Cu}(\mathrm{I})$-catalyzed rearrangement leading to an enal side chain as in $\mathbf{1 3}$, as opposed to the cyclopropanation product $\mathbf{1 4}$ which was observed with the Pt(II)-catalyzed rearrangement. This observation was elegantly implemented by Fehr for the synthesis of (-)- $\beta$-Santalol ((-)-15) (Scheme 4), ${ }^{[13 a]}$ an important constituent of East Indian Sandalwood oil obtained from the tree Santalum Album. As this tree is a vulnerable species, it is a global challenge to obtain Sandalwood oil sustainably. $(-)-\beta$-Santalol $((-)-\mathbf{1 5})$ is very appreciated by perfumers for its lactonic sandalwood odour. ${ }^{[16]}$

There are numerous efforts described in the literature and internally at Firmenich for the synthesis of $\beta$-Santalol,[16] based on other catalytic routes towards the preparation of the key intermediate aldehyde 16, which is found in many syntheses. Noteworthy approaches such as Chapuis in 2012[17] and Birkbeck in 2014[18] described different catalytic routes toward 16, shown in Scheme 5. These routes elegantly complement the previous approach of Fehr in $2009,{ }^{[13 a]}$ and differ from the stoichiometric routes described ear-
Stoichiometric approach (1957):<smiles>O=C1CCCCCCCCCCC1</smiles>

(9)

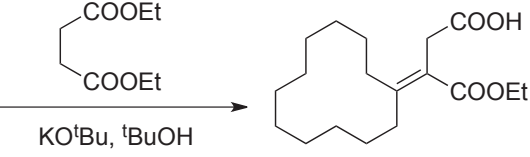

$85 \%$ yield $(E$ fact $=$ ca. 13$)$ a) Polyphosphoric acid b) $\mathrm{H}_{3} \mathrm{O}^{+}$

$47 \%$ yield $(E$ fact $=$ ca. 67$)$

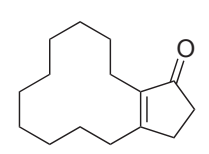

(8)

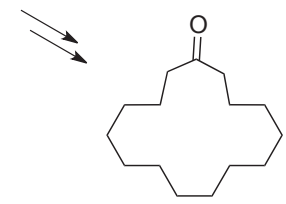

(7)

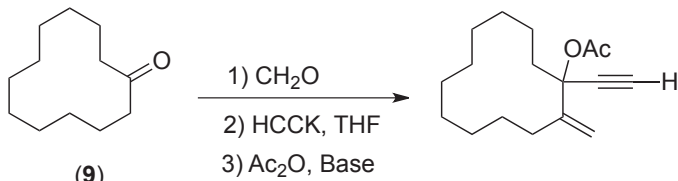

(9)
3) $\mathrm{Ac}_{2} \mathrm{O}$, Base

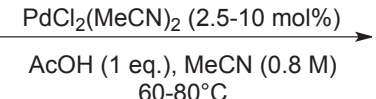

$78-89 \%$ yield

$(E$ fact $=$ ca. 9$)$ 


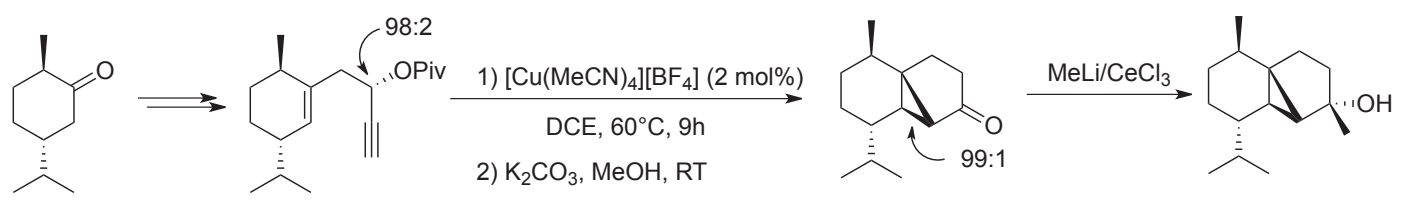

$(+)-(R, R)-$ Tetrahydro-

(11)

$77 \%$ yield

$95 \%$ yield

(10) carvone

Scheme 3. (-)-Cubebol (10) via Cu(1)-catalyzed cycloisomerization.

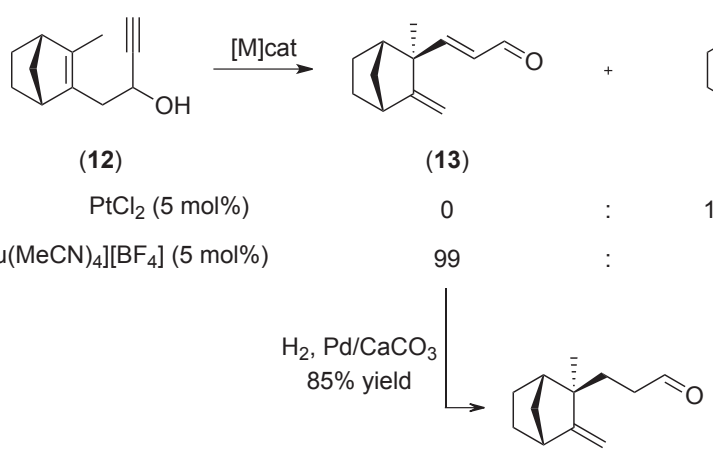

(16)

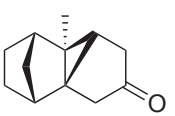

(14)

$100(88 \%$ yield $)$

1 (96\% yield)
Scheme 4. (-)- $\beta$-Santalol ((-)-15) synthesis via $\mathrm{Cu}(\mathrm{I})$-catalyzed cyclization-fragmentation.

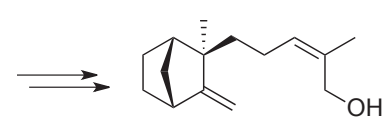

(15)

(-)-beta-Santalol

Stoichiometric approach:

Willis (1979)

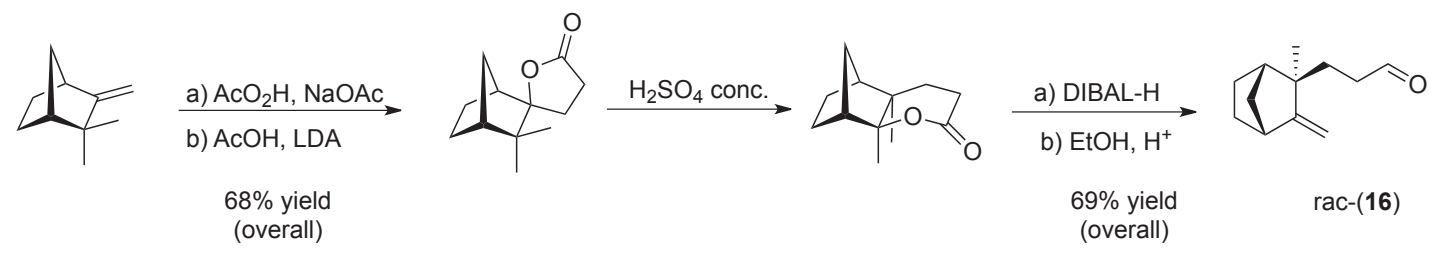

\section{Catalytic approaches:}

Chapuis (2012)

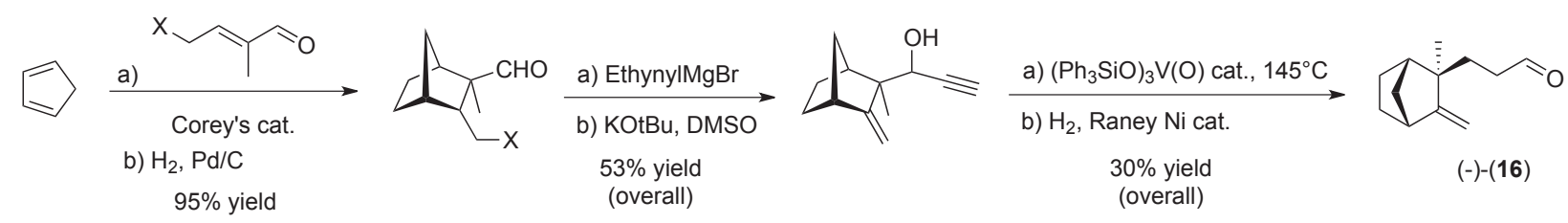

Birkbeck (2014)

1st generation:

$$
\underset{\substack{\mathrm{Znl}_{2}(5 \mathrm{~mol} \%), \mathrm{RT} \\ 45 \% \text { yield }}}{\text { OAc }}
$$

2nd generation:

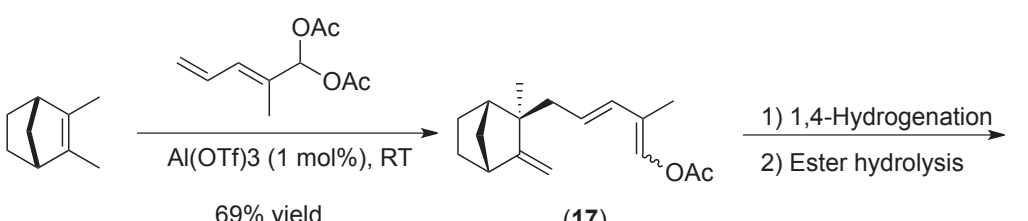

(17)

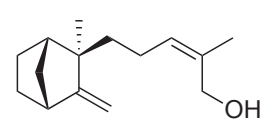

(15)

rac-beta-Santalol

Scheme 5. Comparative synthesis of intermediate $\mathbf{1 6}$ towards $\beta$-Santalol. 
lier, for example see the Willis synthesis in 1979.[19] Birkbeck's second-generation approach is the most atom economical route to date with the preparation of the more advanced dienolacetate 17, which after hydrogenation and hydrolysis gave directly the $\beta$-Santalol (15).

\subsection{Pd-catalyzed Heck Reactions ${ }^{[20,21]}$}

Aldehydes and ketones are two of the most common functional groups in perfumery. Gaudin used a Pd-catalyzed intramolecular Heck reaction followed by isomerization to prepare cyclic ketones and aldehydes. ${ }^{[20]}$ The presence of an allylic alcohol as coupling partner allowed, via a consecutive $\mathrm{Pd}$ (II)-catalyzed isomerization, to furnish aldehyde $\mathbf{1 8}$ and ketone $\mathbf{1 9}$ as shown in Scheme 6 in moderate to high yield.

\subsection{Macrocyclic Synthesis by Metal-catalyzed Reactions ${ }^{[22]}$}

Macrocyclic musks are an important sub-category of the musk family. [23] One of the first syntheses of Muscone (20), in its racemic form, was described by Ruzicka and Stoll in 1934.[24] Continuous improvements of the synthesis of Muscone (20) have been implemented over the years at Firmenich in order to reduce the total number of chemical steps, to use catalytic steps and to reduce the environmental impact of the syntheses. Scheme 7 illustrates the synthesis of Ruzicka and Stoll versus a first improvement by Ohloff in 1967 using the previously seen bicyclopentadecenone $(\mathbf{8})$. ${ }^{[9 \mathrm{~b}]}$

Hereafter are presented three short syntheses of this iconic musk, Muscone (20), from readily available materials and where the key steps are catalytic. In order to shorten the synthesis Schulte-Elte, Hauser and Ohloff explored, in 1979, the use
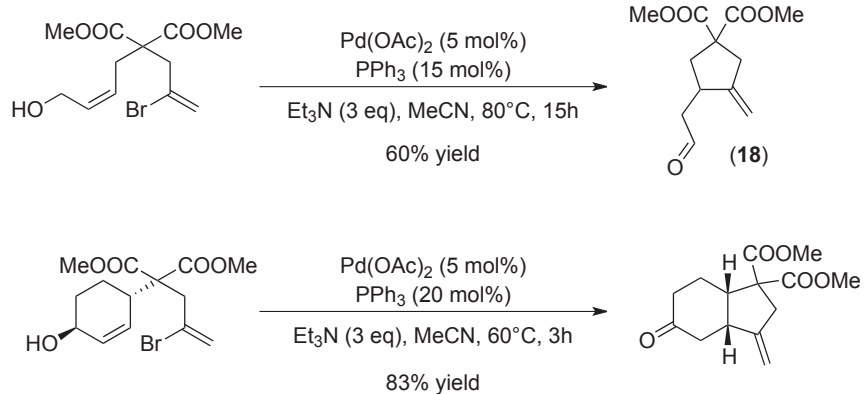

(19)

Scheme 6. Intramolecular relay-Heck reactions.

of cyclododecatriene (21) a precursor of cyclododecanone (9). Dehydrogenation of the macrocyclic dihydropyran $\mathbf{2 3}$ followed by an electrocyclic rearrangement and a hydrogenation step gave Muscone (20) in good yield (Scheme 8). This metal-catalyzed 'borrowing hydrogen transfer' sequence avoided the challenging hydrogenation of the dione $\mathbf{2 4}$ into $\mathbf{2 0}$ as shown in Scheme 7. The starting macrocyclic dihydropyran $\mathbf{2 3}$ was obtained by a high dilution acid-catalyzed cyclization of the corresponding hydroxyl acetal $\mathbf{2 5}$ which in turn was readily available from cyclododecatriene (21) (Scheme 8). ${ }^{[22 a, 25]}$

The second example started from cyclododecanone (9) and used a three-carbon elongation methodology to attain the C15macrocyclic ketone 20, a strategy found in many syntheses of C15macrocyclic ketones. In this example, Rautenstrauch, Snowden and Linder described a short synthesis of racemic Muscone (20) starting from methallylated cyclododecanone $26 .{ }^{[22 b]}$ Their route used a Lewis acid catalyzed ene-reaction followed by an anion-

Ruzicka (1934)<smiles>O=C1CCCCCCCCCCCCC1</smiles>

(7)

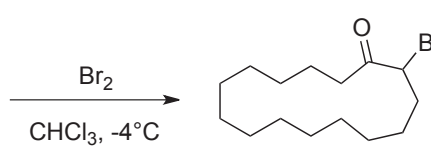

$33 \%$ yield

\section{$300^{\circ} \mathrm{C}$}

$93 \%$ yield

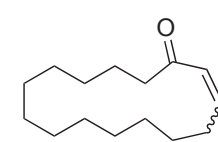

$\sim \mathrm{N}^{3}$

Exaltone@

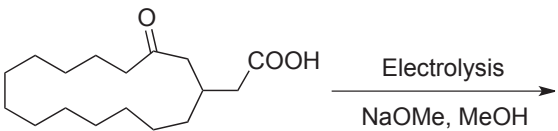

$26 \%$ yield<smiles>C=C1CCCCCCCCCCCCC(=O)C1</smiles><smiles>CCO[R18](N)[Ge]</smiles>

$\mathrm{OH}$

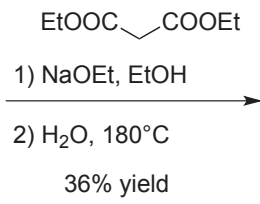

$36 \%$ yield<smiles>CCCCCCCCCCCC(=O)CC(C)C</smiles>

(20)

Ohloff (1967)

rac-Muscone<smiles>O=C1CCCCCCCCCCC1</smiles>

(9)<smiles>CCCCCCCC1=C(CCCCCCCCCCCC(C)(C)C)C(=O)CC1</smiles>

(8)<smiles>CCCCCCCC1CC(C(=O)OCC)C(=O)C1CCCCCCC</smiles>

2) $\mathrm{NaOH}$ then $\mathrm{H}_{3} \mathrm{O}^{+},-\mathrm{CO}_{2}$

$$
\begin{gathered}
90 \% \text { yield } \\
\text { from }(8)
\end{gathered}
$$

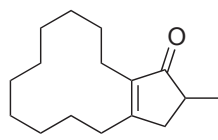

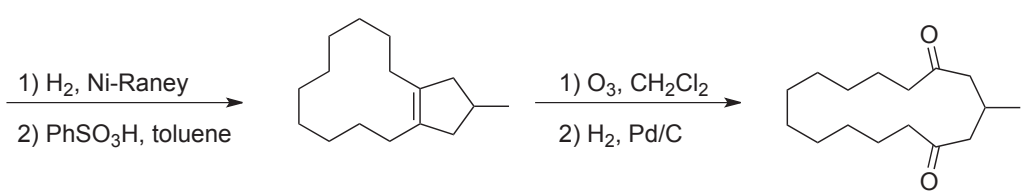

(24)

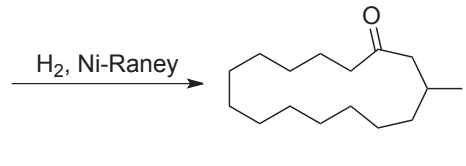

(20) 
<smiles>C=CC/C=C\C/C=C\C/C=C\CC</smiles>

(21)<smiles>C=C(C)CC(O)CC/C=C\CCC1OCCCO1</smiles>

(25)

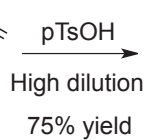

$75 \%$ yield

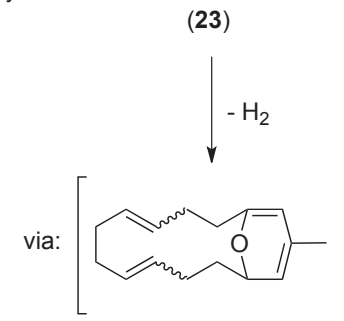

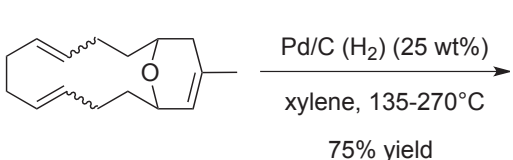

$75 \%$ yield

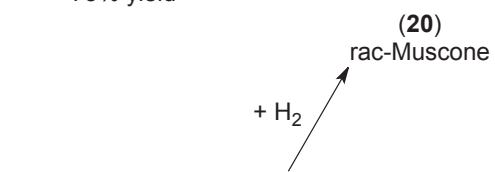<smiles>CCCCCCCCCCCCC(=O)CC(C)C</smiles>

(20)

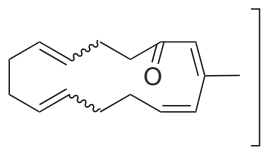

Scheme 8. Muscone (20) synthesis from cyclododecatriene (21).

ic $\beta$-cleavage of the potassium salt of homo-allylic alcohol 27. Finally, $\mathrm{Pd} / \mathrm{C}$-catalyzed hydrogenation of enone $\mathbf{2 8}$ gave Muscone (20) in high yield (Scheme 9). [22b]

The third example shown below demonstrates that the synthesis of Muscone (20) has been continuously improved over the years at Firmenich. Indeed, recently Knopff and Fehr described an elegant synthesis of optically enriched $(R)$-Muscone $(R-20),[26$ which is the stronger of the two enantiomers, and very appreciated by perfumers for its strong animal musk character. They were able to generate enone $\mathbf{2 9}$ in optically active form via an intramolecular aldol reaction of dione $\mathbf{2 4}$ using a chiral alkoxide (Scheme 10). The synthesis was completed by the fragmentation into the macrocyclic ynone using Eschenmoser's conditions ${ }^{[27]}$ followed by a $\mathrm{Pd} / \mathrm{C}$ catalyzed hydrogenation into $(R)-\mathbf{2 0}$ in high yield. The use of dione 24, first described by Ohloff in 1967, shows that 40 years later, improvements can still be made and successfully implemented on industrial scale.

\subsection{Olefin Trimerization ${ }^{[28]}$}

As seen in the above paragraph, macrocyclic odorants are ubiquitous perfumery ingredients with examples of macrocyclic epoxides, macrocyclic ketones and macrocyclic lactones, the latter having a characteristic animalic musk odor. The example below shows that, as early as the 1960s, Schulte-Elte and Ohloff<smiles>O=C1CCCCCCCCCCC1</smiles>

(9)<smiles>C=C(C)CC1CCCCCCCCCC1=O</smiles>

(26)

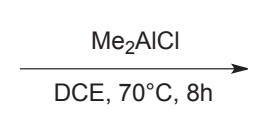

CE, $70^{\circ} \mathrm{C}, 8 \mathrm{~h}$

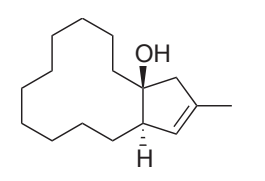

(27)

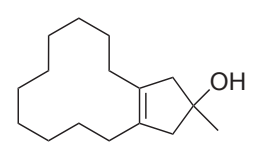

$18 \%$ yield
Scheme 9. Muscone (20) from cyclododecanone (9) using an anionic fragmentation.<smiles>CC1=C[C@@H]2CCCCCCCCCC[C@]2(O)C1</smiles>

(27)

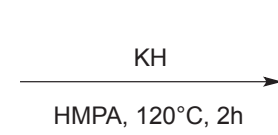

HMPA, $120^{\circ} \mathrm{C}, 2 \mathrm{~h}$

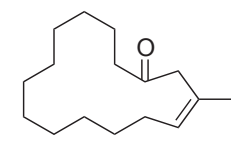

(28)

$38 \%$ yield

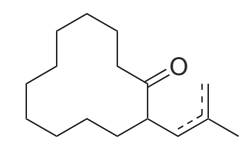

$22 \%$ yield

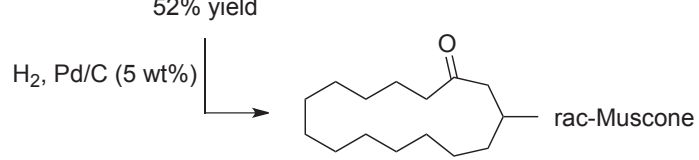

(20)

$94 \%$ yield

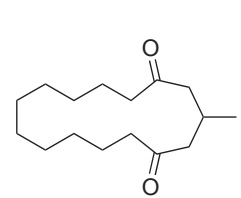

(24)

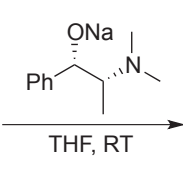

$95 \%$ yield

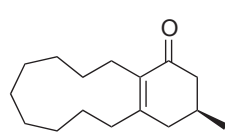

(S)-(29) ee $=64-96 \%$
1) $\mathrm{TsNHNH}_{2}, \mathrm{AcOH}$ cat.

$\mathrm{AcOOH}$

3) $\mathrm{H}_{2}, \mathrm{Pd} / \mathrm{C}$

$70 \%$ yield

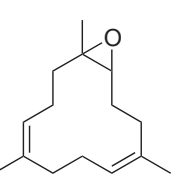

(30)

Cedroxyde $^{\circledR}$

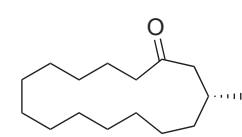

$(R)-(20)$

(R)-Muscone
Scheme 10 . Synthesis of optically enriched (R)-Muscone (20).

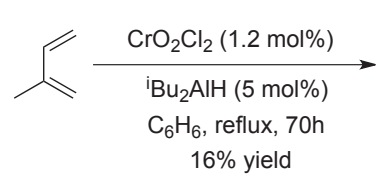

isomeric mixture
$\frac{\mathrm{AcOOH}, \mathrm{AcONa}}{\mathrm{CH}_{2} \mathrm{Cl}_{2}, \mathrm{RT}}$

$63 \%$ yield

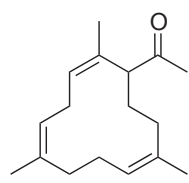

(31)

$\operatorname{Trimofix}^{\circledR}$ (IFF)

Scheme 11. Cyclotrimerization of isoprene to generate macrocyclic epoxides. 
took advantage of Wilke's olefin trimerization catalyzed by $\mathrm{Ni}$ or $\mathrm{Cr}^{[29]}$ to build functionalized $\mathrm{C} 12$-macrocyclic rings with interesting olfactory properties (Scheme 11). [28]

Despite the formation of isomeric mixtures, the cyclotrimerization of isoprene (Scheme 11) followed by mono-epoxydation with peracetic acid gave rise to the macrocyclic epoxide, Cedroxyde ${ }^{\circledR}$ (30) with interesting woody notes, related to the known Trimofix ${ }^{\circledR}$ (31) commercialized by IFF. ${ }^{[30]}$

\section{Metal-catalyzed Carbonylation}

In this second section, our journey into catalytic efforts performed at Firmenich continues with metal-catalyzed carbonylation reactions for the synthesis of esters and aldehydes, two ubiquitous functional groups found in perfumery molecules.

\subsection{Palladium-catalyzed Carbonylation Reaction ${ }^{[31,32]}$}

In the 1990s it became important to develop an efficient onecarbon homologation of allyl alcohols ${ }^{[33]}$ such as farnesol, in order to prepare Ambrox $^{\odot}$ (32). ${ }^{[34]}$ Inspired by the work of Murahashi, [35] Rautenstrauch found that quaternary allyl ammonium salts could be efficiently transformed into $\beta, \gamma$-unsaturated esters under $\mathrm{CO}$ pressure with a Pd-based catalyst. Geranyl diethyl amine (33), ${ }^{[41]}$ readily available from the sesquiterpene myrcene (34), was cleanly converted into the homologated ethyl ester $\mathbf{3 5}$ in good yield (Scheme 12). ${ }^{[36]}$ Recently, Chapuis reinvestigated this reaction in the context of a formal new synthesis of $\mathrm{rac}-\mathrm{Ambrox}^{\odot}(32)$ from farnesyl diethyl amine (36) (Scheme 12). ${ }^{[31]}$

\subsection{Cobalt-catalyzed Pauson-Khand Carbonylation Reaction ${ }^{[37]}$}

Ferdinand Naef, former Head of Research and Development at Firmenich (1990-2005), wanted to investigate whether a catalytic version of the Pauson-Khand reaction could be developed ${ }^{[33,37]}$ in order to synthesize 2-pentylcyclopent-2-en-1-one (37), an important precursor of Hedione ${ }^{\circledR}(\mathbf{6}) .{ }^{[8,38]}$ This turned out to be possible and the first catalytic version of the Pauson-Khand reaction using 1-heptyne and ethene as coupling partners was reported by Rautenstrauch and Keim (Aachen) in 1990 (Scheme 13).[37b,c]

Despite the moderate yield, the reaction was highly selective in favor of the desired 2-pentyl cyclopentenone (37) (>98\%). The other side products detectable by GC in small amounts (7-8\%) were the result of cyclotrimerization ( 2 heptyne +1 ethene) and of the formation of cyclopentadienones $(2$ heptyne $+1 \mathrm{CO})$. $^{[37 \mathrm{a}]}$ Furthermore, compared to the other stoichiometric reactions described for the preparation of $\mathbf{3 7}$ (see Scheme 13 for one example), ${ }^{[8,38]}$ this cyclocarbonylation proceeds in only one step.

\section{Copper-catalyzed C-C Bond Coupling[39]}

Galbanolene (38), isolated from the Galbanum essential oil is highly appreciated in perfumery for its green, fruity top note. As there are several possible configurational isomers for this undecatriene, it was found that only the $3 E$, $5 Z$-isomer is appreciated by perfumers as opposed to the $3 E, 5 E$-isomer (all trans) which has an undesirable fishy-putty note and should therefore be avoided. [3b,39a] A stereoselective synthesis of $3 E, 5 Z-38$ was developed by Chapuis ${ }^{[39 b]}$ and is based on, as a key step, a copper-catalyzed alkynylation reaction followed by a Hofmann elimination in the final step, providing the desired product as a single isomer (Scheme 14).

\section{Catalytic Isomerization of $\mathrm{C}=\mathrm{C}$ Double Bonds}

\subsection{Rhodium-catalyzed Isomerization ${ }^{[40]}$}

The Rh-catalyzed enantiospecific isomerization of allyl amines has allowed the Takasago company to produce optically active citronellal (39) from geranyl diethyl amine (33) (Scheme 15). ${ }^{[11]}$ Citronellal (39) characterized by a rose lemongrass note is an important starting material for other Perfumery \& Flavor ingredients, i.e. menthol.[3] A decade later, as the availability of a large number of chiral diphosphines increased, ${ }^{[42]}$ Chapuis

Rautenstrauch (1991-1992):
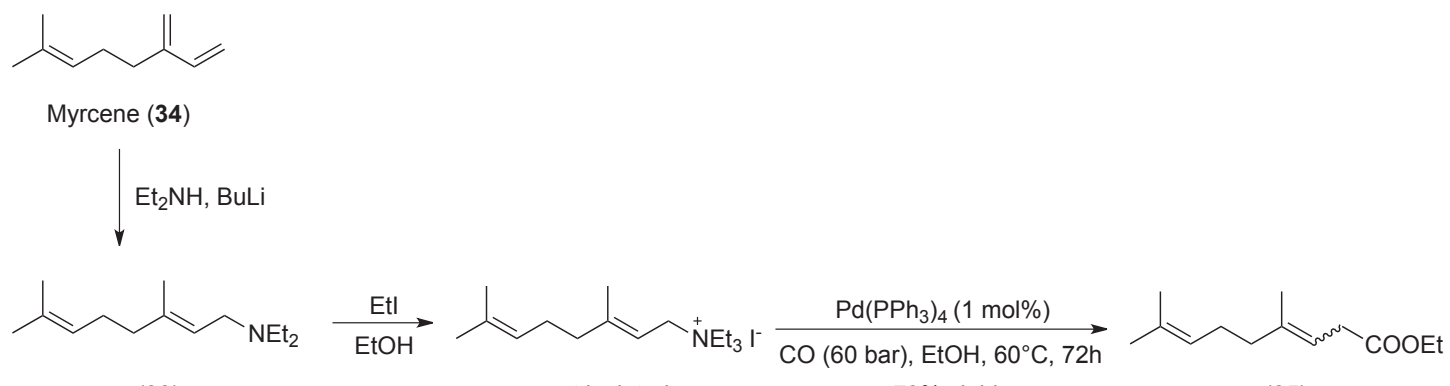

(33) not isolated $73 \%$ yield

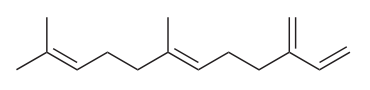

Farnesene

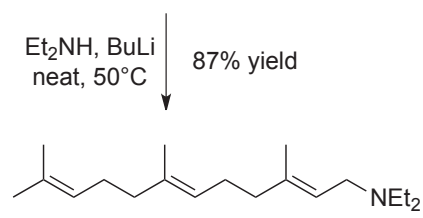

(36)

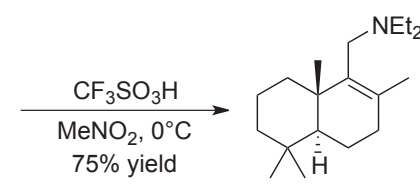
2) $\mathrm{Pd}\left(\mathrm{PPh}_{3}\right)_{4}(1.5 \mathrm{~mol} \%)$ $\mathrm{CO}(60 \mathrm{bar}), 60^{\circ} \mathrm{C}$ $22-31 \%$ yield

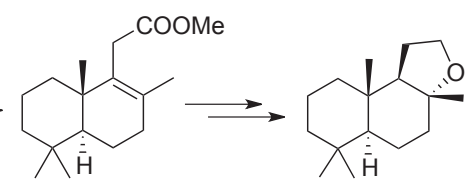

(32) 
Scheme 13. Comparative synthesis of 2-pentylcyclopent-2-en1-one (37) via stoichiometric reaction and by catalytic PausonKhand cyclisation.<smiles>CCCCCC(=O)O</smiles><smiles>CCCCC=C1CCCC1=O</smiles>

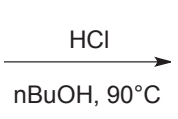

$87 \%$ yield

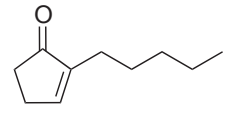

(37)

Catalytic cyclocarbonylation (Pauson-Khand):

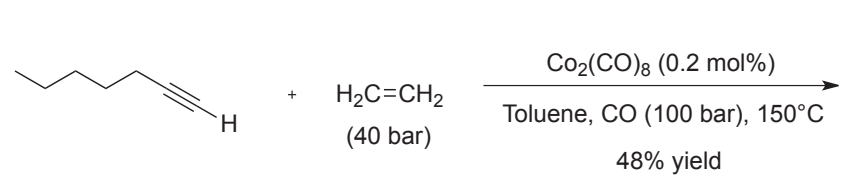

$$
48 \% \text { yield }
$$

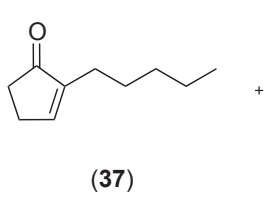

Sel.: $98-99$

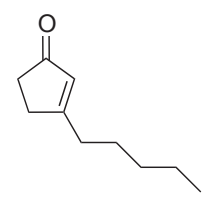

$2-1$
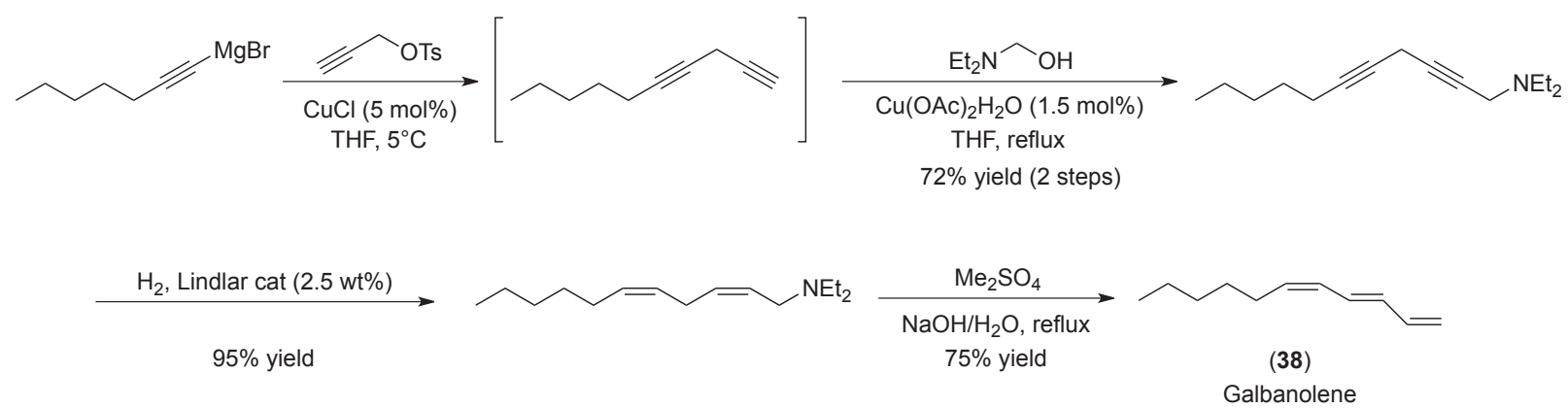

Scheme 14. Stereoselective synthesis of $(3 E, 5 Z)-1,3,5-$ undecatriene (38) via copper catalysis.

discovered that geranyl diethyl amine (33) could be isomerized with $\mathrm{Rh}$-complexes bearing JOSIPHOS type ligands instead of the original BINAP one. ${ }^{[40]}$ Both enantiomers of citronellal (39) were then obtained in high enantioselectivity $(92-97 \%$ ee $)$ and in high yield. ${ }^{[40 c]}$ Chapuis recently extended this process to the isomerization of farnesyl diethyl amine (36), readily available from farnesene. Dihydrofarnesal (40) was then produced with a high enantioselectivity (92\% ee) and in high yield (90\% yield). ${ }^{[40 \mathrm{~d}]}$
With the optically active dihydrofarnesal (40) in hand, a synthesis of (-)-Ambrox ${ }^{\odot}(\mathbf{3 2})$ was then accomplished (Scheme 15). [40d]

\subsection{Ruthenium-catalyzed Isomerization ${ }^{[43]}$}

Using Chaudret's catalyst $\left(\left[\mathrm{RuH}\left(\eta^{5}-\mathrm{C}_{8} \mathrm{H}_{11}\right)_{2}\right]\left[\mathrm{BF}_{4}\right]\right)^{[44]} \mathrm{Fehr}$ showed that the isomerization of allylic alcohols into aldehydes could be performed stereospecifically and that the presence of a vicinal alcohol group directed the $\mathrm{Ru}-\mathrm{H}$ insertion into the $\mathrm{C}=\mathrm{C}$

Takasago isomerisation:

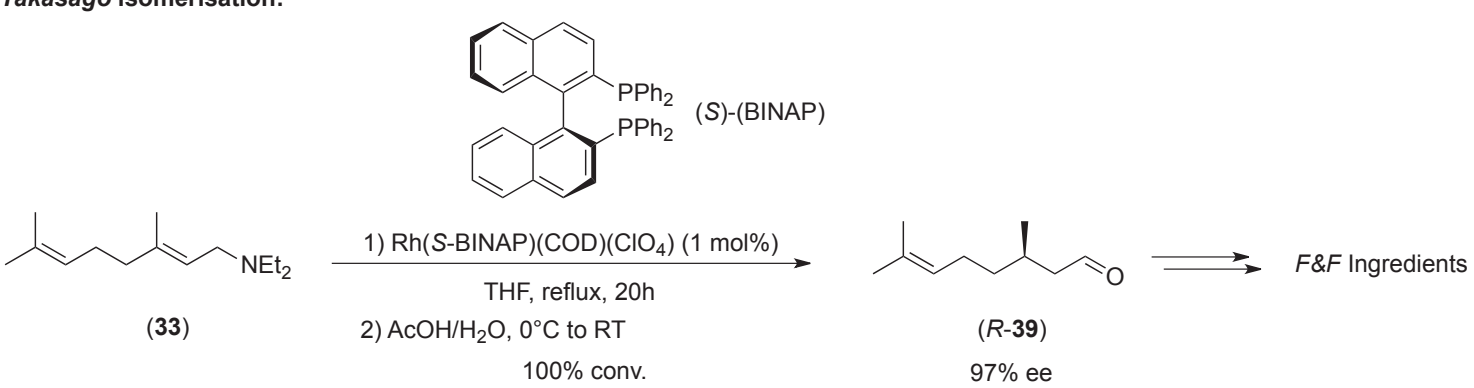

Farnesyl amine isomerisation

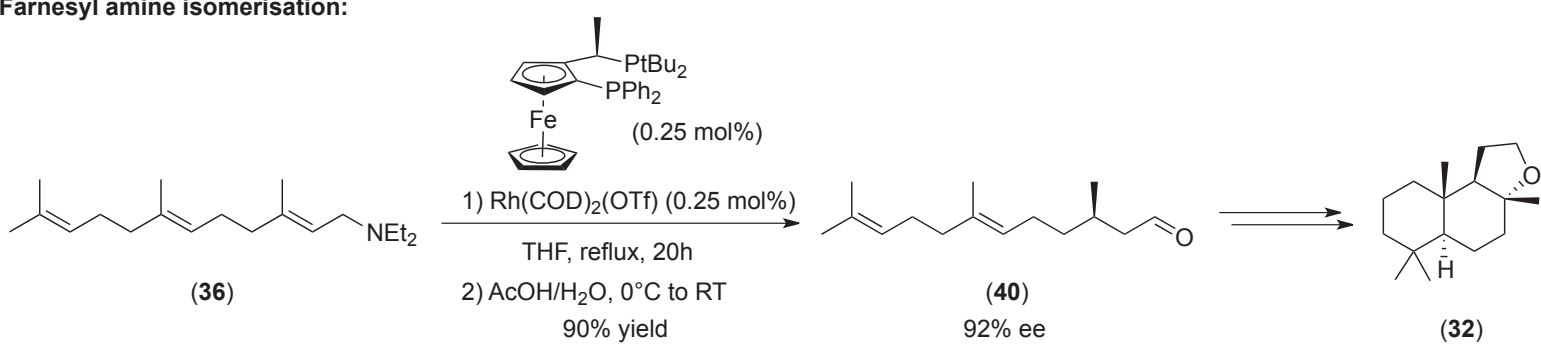


bond in a stereospecific manner.[43b,c] This observation led, after in situ reduction of the intermediate lactol, to the facile synthesis of trans-tetrahydrofuran (42) (Scheme 16). ${ }^{[43 a]}$ Alternatively, the corresponding trans-lactone (43) could also be obtained by in situ dehydrogenation of the same lactol (41) with Ikariya's complex (Scheme 16). ${ }^{[43 a]}$

Damascones are important constituents of the floral family of perfumery ingredients, ${ }^{[3]}$ among them alpha-Damascone (44) is characterized by an intense rose scent with some green and fruity aspects. The first selective synthesis of this isomer was reported in 1975 by Schulte-Elte et al..$^{[45]}$ and started from dehydrolinalol (45) as shown in Scheme 17. The key step was a $\mathrm{Cu}$-catalyzed rearrangement of acetate 46 into the trienone $\mathbf{4 7}$. Finally an acidcatalyzed cyclization gave the desired alpha-Damascone (44). This ingredient became very important commercially and several syntheses have been reported over the years. One may cite the improvements made by Naef and Decorzant and reported in 1986.[46] The key step of their synthesis is the addition of allyl magnesium chloride to the stable ketene $\mathbf{4 8}$ obtained in four steps from citral (49) giving the desired alpha-Damascone (44) after hydrolysis and isomerization of the terminal double bond (Scheme 17). The use of ketene $\mathbf{4 8}$ as an electrophile instead of the corresponding ester prevented the double addition of the Grignard reagent as the product in solution is stable in the form of enolate 50. Another elegant way to solve the Grignard double addition problem was to use a strong base during the addition of the Grignard reagent to ester 51, as reported by Fehr and Galindo. ${ }^{[47]}$ Indeed, the strong base generates enolate $\mathbf{5 0}$, and therefore prevented the double addition of the Grignard reagent. This strategy later allowed the authors to perform a catalytic enantioselective protonation of enolate $\mathbf{5 0}$ in order to access the more olfactively intense and appreciated $(S)$ (-)-enantiomer of 44. ${ }^{[48]}$

Another interesting use of ruthenium-catalyzed isomerization of $\mathrm{C}=\mathrm{C}$ double bonds is in the synthesis of the sandalwood ingredient Firsantol ${ }^{\circledR}(\mathbf{5 2})$. This is an improvement versus the previous synthesis of 52, developed in 1984 by Schulte-Elte, which relied on a stoichiometric $\mathrm{LiAlH}_{4}$ reduction of ester $\mathbf{5 3}$, obtained by Claisen-Johnson rearrangement with ethyl orthopropionate and alcohol 54 (Scheme 18). ${ }^{[49]}$ The four diastereomers of alcohol $\mathbf{5 2}$ were evaluated olfactively and it was found that the $(-)-(1 ' R, 2 R)$ diastereomer was the

Scheme 16. Tricyclic trans-furan (42) and trans- $\gamma$-butyrolactone (43) via $\mathrm{OH}$ directed $\mathrm{Ru}$-catalyzed isomerization.

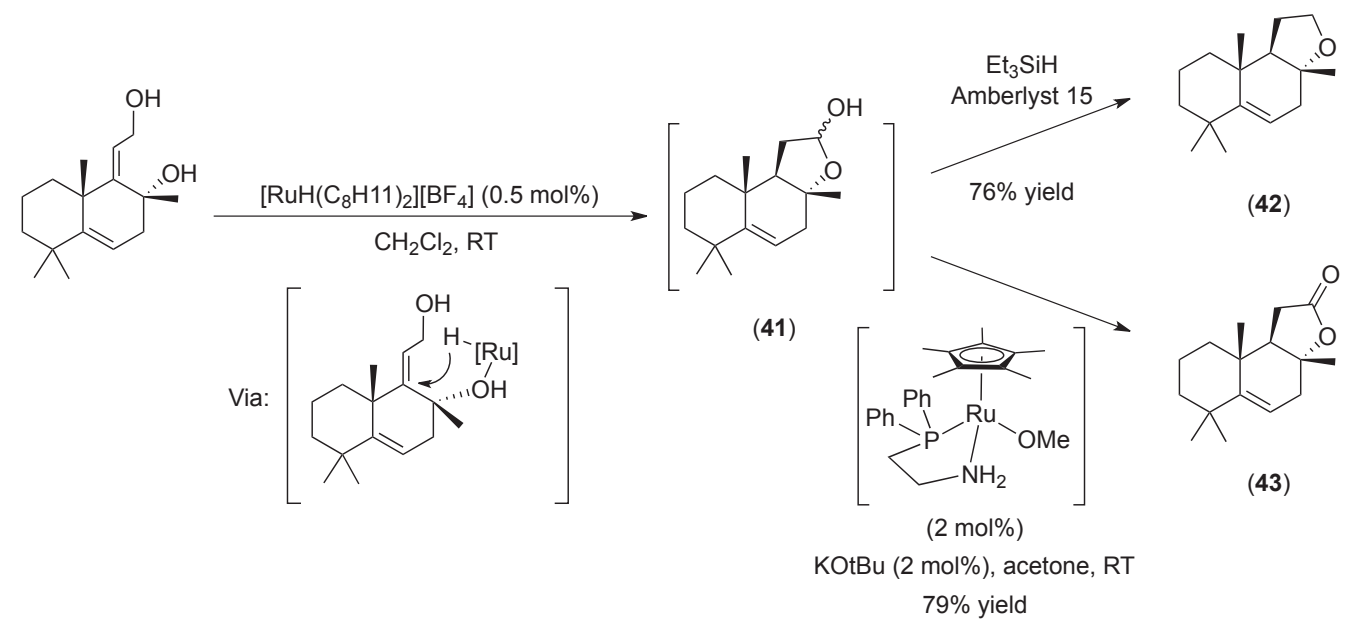

Schulte-Elte (1975):
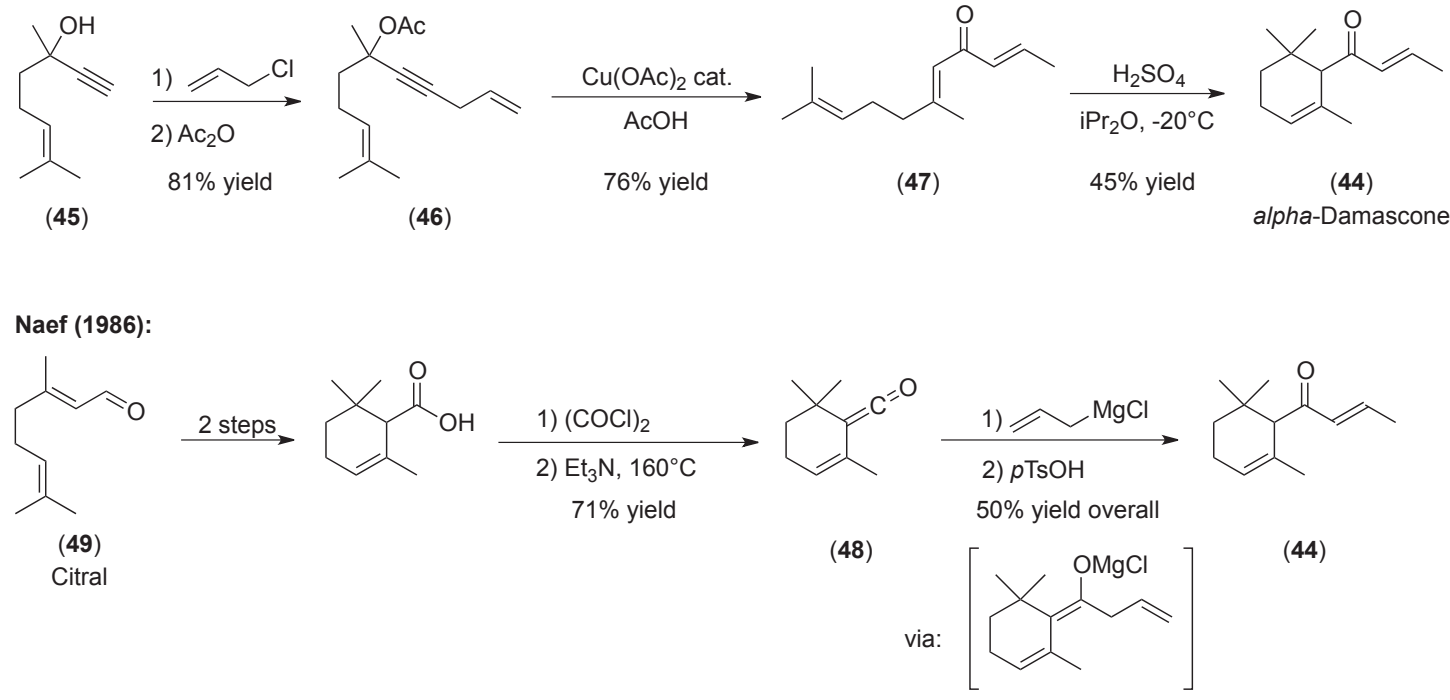

Fehr (1988-1996):<smiles>COC(=O)C1C(C)=CCCC1(C)C</smiles><smiles>C=CCN(C)Cl</smiles>

(51)<smiles>C=CC/C(OC)=C1\C(C)=CCCC1(C)C</smiles>

(50)

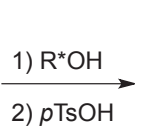<smiles>C/C=C/C(=O)[C@H]1C(C)=CCCC1(C)C</smiles>

(S)-(-)-(44)

Scheme 17. Synthesis of alpha-Damascone (44). 
strongest, more sandalwood and most pleasant of the four. ${ }^{[43 c]}$ To obtain the highest amount of the best isomers, Chapuis described in 1996, ${ }^{[43 c]}$ a tandem $\mathrm{Ru}$-catalyzed $\mathrm{C}=\mathrm{C}$ bond isomerization-Claisen rearrangement ${ }^{[50]}$ for the preparation of aldehyde $\mathbf{5 5}$, which after $\mathrm{Ru}$ catalyzed hydrogenation of the carbonyl group, provided the desired sandalwood alcohol 52 in high yield (Scheme 18). ${ }^{[54 c, 70]}$

\subsection{Photochemical Isomerization [51]}

Recently, there has been an increasing trend toward the use of photochemical processes, in particular those based on photoredox catalysis. ${ }^{[52]}$ Indeed, photochemical processes allowed to produce transient reactive species, used either in stoichiometric or catalytic amounts, under mild and efficient manner compatible with many functional groups. These characteristics give photochemical processes a low environmental footprint by using protecting group-free syntheses and by using non-toxic radical initiators as in the case of photoredox catalysis. Photochemical processes have been used as early as the 1960s, with one important example being the synthesis of rose oxide (56), by Ohloff using a dye-sensitized photooxygenation of (-)-citronellol (57). ${ }^{[53]}$ The hydroperoxide was then reduced and the diol cyclized under acidic conditions (Scheme 19). Another example using photochemistry is the isomerization of $\mathrm{C}=\mathrm{C}$ bonds to the more stable $(E)$-configuration with a photo-generated thiyl radical as described by Schulte-Elte in 1976.[51] The author described that irradiation with a mercury lamp of a solution containing a catalytic amount of diphenyldisulfide produced a thiyl radical that could add reversibly to diene $\mathbf{5 8}$, thus allowing the isomerization towards the more stable diene isomer (Scheme 19).

\section{Ruthenium-catalyzed Hydrogenation Reactions [54]}

The efforts towards producing (+)-cis-methyl dihydrojasmonate $((1 R, 2 S)-6)$ in an enantiomerically and stereochemically enriched form on industrial scale led chemists at Firmenich to study homogeneous catalyzed hydrogenation at the end of 1990s and build up a huge amount of expertise which is still present today. ${ }^{[55]}$

\subsection{Ru-catalyzed Hydrogenation of $C=C$ Double Bonds ${ }^{[56]}$}

Over 50 years after its initial discovery by Demole and Lederer, ${ }^{[8]}$ Hedione (6), commercialized as a near-equilibrium mixture of the racemic trans/cis isomers (90-93/7-10), remains a blockbuster in modern perfumery. ${ }^{\left[{ }^{[8]}\right.}$ It was soon realized that only the cis-isomer $(1 R, 2 S)-6$ had an intense and distinct jasmine odor (Fig. 2) and it soon became an important industrial target.

Syntheses of optically pure $(1 R, 2 S)-6$ were initially long and tedious, for an example developed by Fehr (Scheme 20). ${ }^{[57]}$ The shortest route towards $(1 R, 2 S)-\mathbf{6}$ under neutral conditions in order to avoid epimerization was a metal-catalyzed hydrogenation of the dehydro compound $\mathbf{5 9}$ (Scheme 20). ${ }^{[56,58]}$ Based on previous work in the literature, ${ }^{[59]}$ Rautenstrauch et al. first tried to generate and test a highly electrophilic, dicationic ruthenium(II) system

Schulte-Elte's synthesis of Firsantol (1984):

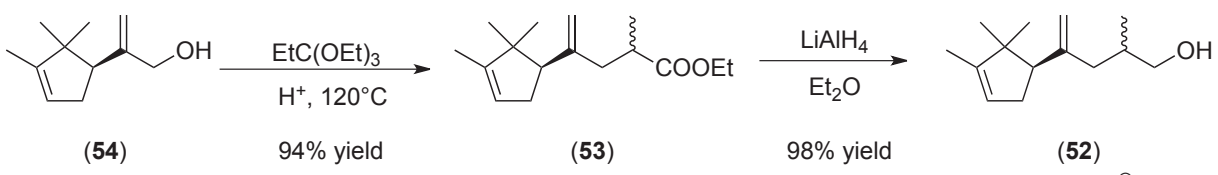

Chapuis's synthesis of Firsantol (1996):
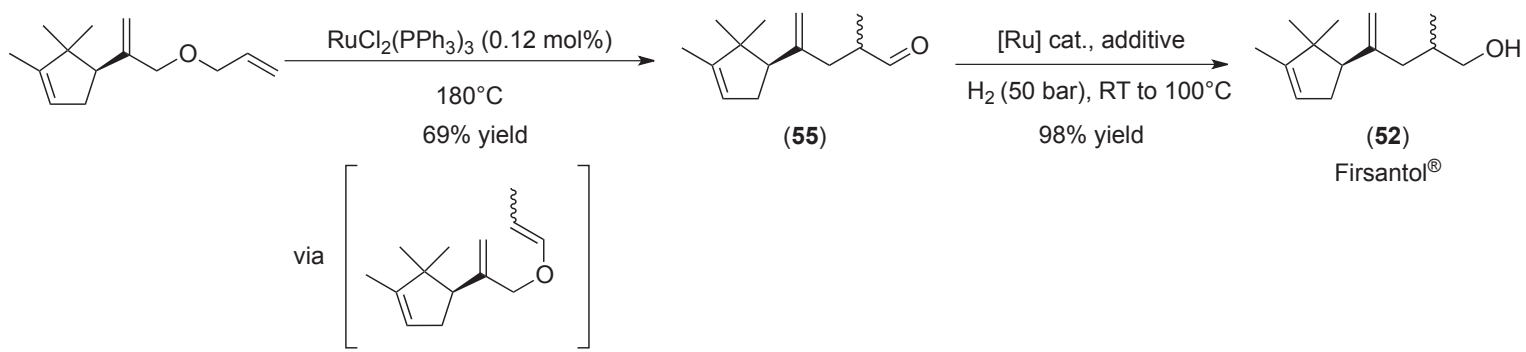

Firsantol $^{\circledR}$

Scheme 18. Comparative synthesis of the sandalwood ingredient Firsantol ${ }^{\circledR}(\mathbf{5 2})$.

Ohloff photo-oxygenation (1961)<smiles>CC(C)=CCC[C@H](C)CCO</smiles>

(57)

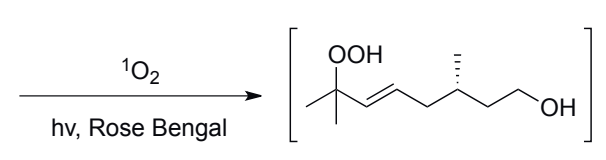

$60 \%$ sel.
Scheme 19. Early photochemical processes at Firmenich.

Schulte-Elte photo-isomerisation (1976)<smiles>C=C/C(C)=C/CCC(C)(C)O</smiles>

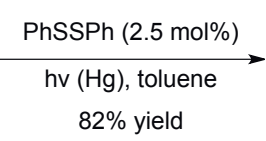<smiles>C=C/C=C\CCC(C)(C)O</smiles>

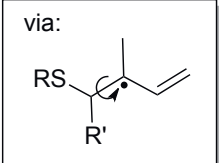




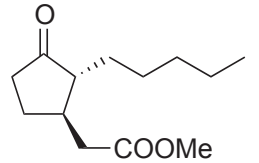

$(1 R, 2 R)-6$

"Weak, more earthy than floral"

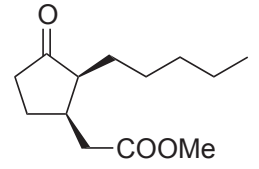

$(1 R, 2 S)-6$

"More powerful, jasmine"
Fig. 2. Methyl dihydrojasmonate (6) isomers.

with non-coordinating counter anions, as he observed that ruthenium complexes with coordinating anions were inefficient for the hydrogenation of the tetrasubstituted double bond present in $\mathbf{5 9}$. In collaboration with Professor Genêt (Paris), they optimized the reaction conditions and the pre-catalyst was isolated and identified. It turned out to be the mono-cationic hydrido ruthenium species 60, instead of the expected dicationic species (Scheme $20)$. The structure was later confirmed by X-ray analysis done in collaboration with Professor Bergens (Alberta).

As illustrated in Scheme 20, the hydrogenation approach towards $(1 R, 2 S)-6$ is a highly atom economic and stereoselective transformation, despite being stoichiometric in hydrogen. In contrast, in the approach described by Fehr ${ }^{[57]}$ a stoichiometric borane reduction was needed to prepare the optically active alcohol $\mathbf{6 1}$, followed by two diastereoselective steps in order to complete the synthesis of $(1 R, 2 S)-6$.

An improved version of the Rautenstrauch process is still used at Firmenich today for the synthesis of (+)-cis-methyl dihydrojasmonate (6) on a multi-ton p.a. scale.

\subsection{Ru-catalyzed Hydrogenation of 1,4-Diene ${ }^{[60]}$}

Cis $-\mathrm{C}=\mathrm{C}$ double bonds are commonly found in perfumery ingredients. Examples are cis-3-hexenol (also known as Pipol or
Leaf Alcohol) characterized by a powerful, fresh and intensive green, freshly cut grass odor.[61] The efforts towards an efficient synthesis of cis- $\mathrm{C}=\mathrm{C}$ double bonds which do not rely on heterogeneous hydrogenation of alkynes, especially for trisubstituted $\mathrm{C}=\mathrm{C}$ double bonds, led Dupau ${ }^{[54 \mathrm{~b}, 60 \mathrm{a}]}$ to improve/industrialize the $\mathrm{Cp} * \mathrm{Ru}$-catalyzed hydrogenation $\left(\mathrm{Cp}^{*}=\right.$ pentamethyl cyclopentadienyl) of dienes discovered by Driessen-Hölscher for the hydrogenation of sorbic acid. ${ }^{62]}$ This ruthenium-catalyzed hydrogenation of dienes was later elegantly applied by Fehr to the hydrogenation of dienyl acetate 17, in the context of (-)- $\beta$-Santalol (Scheme 21). ${ }^{[60 \mathrm{~b}]}$ The latter stereoselective hydrogenation has a much better environmental footprint than the previously used Corey's strategy to introduce the Z-allylic alcohol 15.[13a]

\subsection{Ru-catalyzed Hydrogenation of $\mathrm{C}=\mathrm{O}$ Double Bonds ${ }^{[54]}$}

After successfully tackling the selective hydrogenation of $\mathrm{C}=\mathrm{C}$ double bonds with homogeneous catalysts on industrial scale, the next challenge was the replacement of the stoichiometric reduction of carbonyl functionalities (aldehydes, ketones and esters ${ }^{[63]}$ into their corresponding alcohols by a metal-catalyzed hydrogenation. Indeed, the reduction of these functional groups is currently done industrially with stoichiometric reagents based on $\mathrm{Al}, \mathrm{B}$ and $\mathrm{Si}$ (e.g. $\mathrm{LiAlH}_{4}, \mathrm{NaBH}_{4}$, polymethylhydrosiloxane (PMHS), ...). Therefore the reduction generates a lot of waste (Al and Si salts) as reflected by a high $E$-factor and the manipulation of these reagents on scale is potentially hazardous. The $E$-factor of an alternative catalytic reaction using dihydrogen gas will be much smaller than the stoichiometric reduction (Scheme 22).

\subsubsection{Hydrogenation of Aldehydes and Ketones ${ }^{[64-67]}$}

In the late 1990s, pioneering work in the field of ketone and aldehyde hydrogenation was done by Noyori using $\mathrm{Ru}(\mathrm{II})$ -

(1R,2S)-Methyl dihydrojasmonate by Claisen-Ireland rearrangement and diastereoselective epoxydation (C. Fehr):

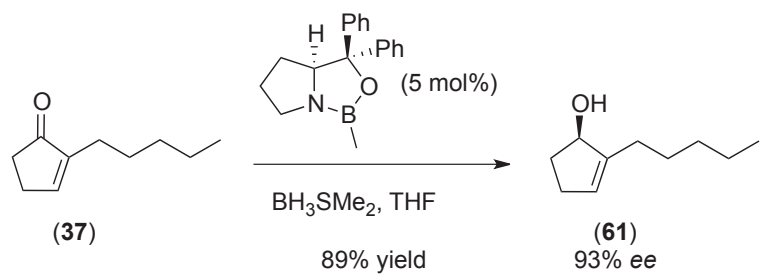

$89 \%$ yield

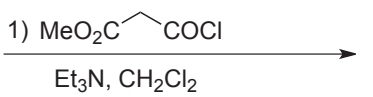

2) $\mathrm{NaH}, \mathrm{THF}$ then TMSCI $50-65^{\circ} \mathrm{C}$

3) $\mathrm{H}_{2} \mathrm{O}, \mathrm{NaCl}, \mathrm{NMP}, 140^{\circ} \mathrm{C}$

$69 \%$ yield over all

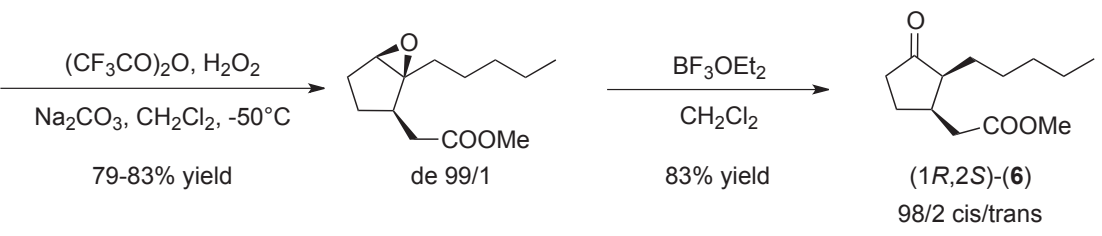

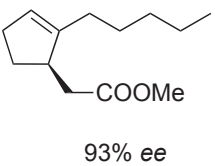

$93 \%$ ee

(1R,2S)-Methyl dihydrojasmonate by catalytic asymetric hydrogenation (V. Rautenstrauch):

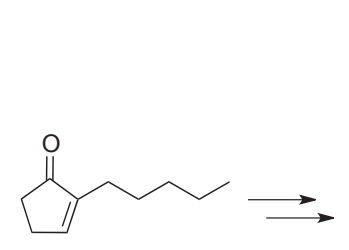

(37)

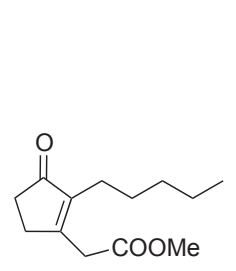

(59)

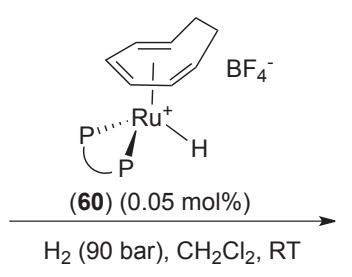

$99 \%$ yield

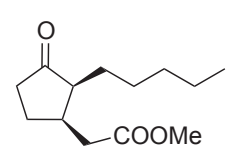

$(1 R, 2 S)-(6)$

$98 / 2$ cis/trans 
Stoichiometric end-game in beta-Santalol synthesis:

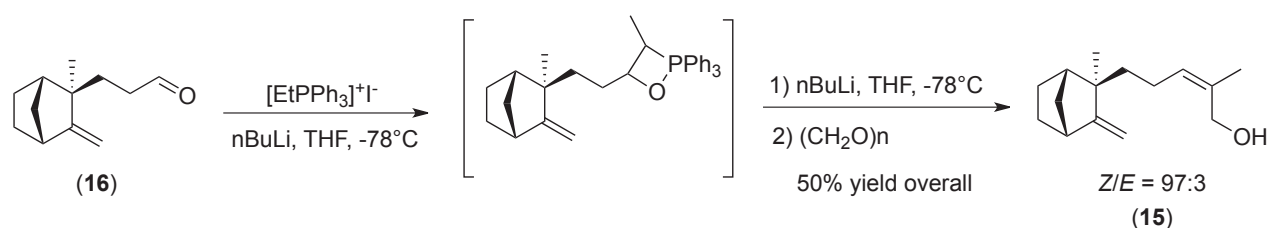

$(-)$-beta-Santalo
Scheme 21. Comparative cis $\mathrm{C}=\mathrm{C}$ double bond formation in the $(-)-\beta$-Santalol ((-)-15) synthesis end game.

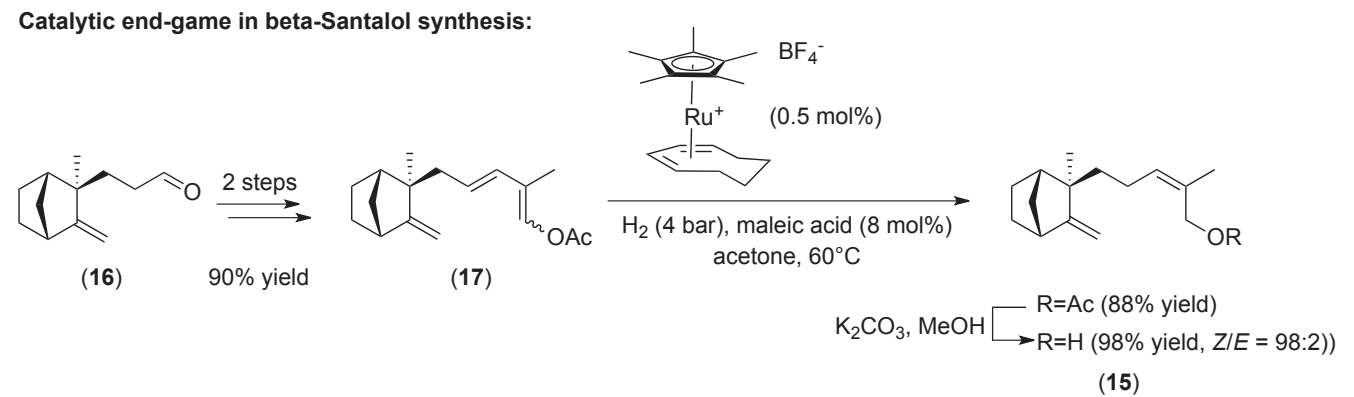

(-)-beta-Santalol

diphosphine-diamine complexes. ${ }^{[68]}$ Inspired by this work, together with a focus on simplicity of Ru(II)-complex synthesis, activity and robustness, Rautenstrauch investigated the use of the inexpensive, achiral ligand, diphenylphosphinoethylamine (DPPEA) (Fig. 3). Gratifyingly, this ligand turned out to give very active ruthenium complexes for the hydrogenation of aldehydes and ketones. ${ }^{664,69]}$

Especially in the context of Sandalwood ingredients, such as Firsantol ${ }^{\circledR}(52)$, Dartanol $^{\circledR}(62)$ and Polysantol ${ }^{\circledR}(63)$, this rutheni-

Previously:

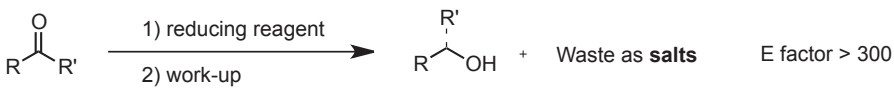

Desired target:

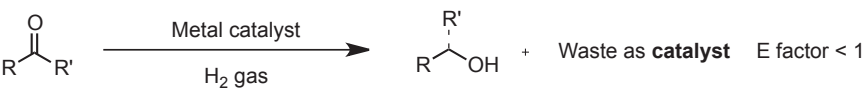

Scheme 22. Comparative $E$-factor between stoichiometric and catalytic reduction of carbonyl groups.

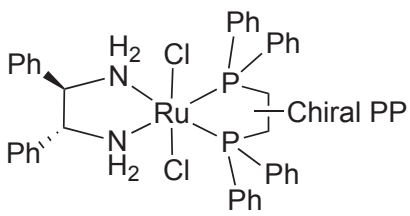

Noyori's Ru(II) catalyst

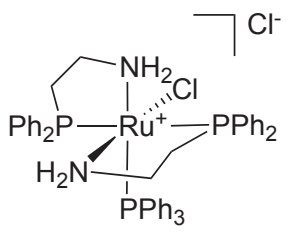

DPPEA-Ru(II) catalyst

Fig. 3. Ru-complexes for aldehydes and ketones hydrogenation.

um complex showed an impressive level of S/C loading (Scheme 23). $[54 \mathrm{c}, 64 \mathrm{~b}]$ This work was recently reviewed by Dupau, ${ }^{[54 \mathrm{c}]}$ where the Ru-catalyzed hydrogenation was compared to previous methods such as the stoichiometric Zn/PMHS reduction and the copper-chromite hydrogenation.

Continuing the research started by Rautenstrauch towards the hydrogenation of aldehydes and ketones, Santoro developed ruthenium complexes with a tetradentate ligand possessing thio-ether groups instead of the widely used phosphorous atoms. He showed that such complexes were found to be highly active and even highly enantioselective towards alcohols and $e e$ values of up to $95 \%$ could be obtained with complex 64 (Scheme 24). ${ }^{65]}$

\subsubsection{Hydrogenation of Aldehydes under Base-free Conditions $^{[54 b, c, 70,71]}$}

The ruthenium(II) complexes reported above needed to have a strong metal alkoxide or hydroxide present in order to be active, presumably in order to transform in situ the $\mathrm{RuCl}_{2}(\mathrm{~L})_{n}$ complex into the productive $\mathrm{RuH}_{2}(\mathrm{~L})_{\mathrm{n}}$ complex. Therefore, some substrates, especially aldehydes, could suffer from the presence of these strong bases and result in the formation of unwanted side products or low yields due to the base-catalyzed polymerization of the substrate prior to hydrogenation. Therefore, solutions were searched for in order to be able to perform this carbonyl reduction under base-free conditions. Noyori was the first to introduce the $\mathrm{Ru}(\mathrm{H})\left(\mathrm{BH}_{4}\right)(\mathrm{L})_{\mathrm{n}}$ complexes as bench-stable masked dihydride complexes that were highly efficient for ketone reduction under hydrogen. ${ }^{[72]}$ Dupau and Bonomo developed ruthenium bis-carboxylate complexes, such as $\mathbf{6 5}$, for the smooth base-free hydrogenation of aldehydes into their corresponding alcohols with a high conversion and high selectivity (Scheme 25). ${ }^{[70]}$ These complexes could be synthesized on large scale industrially, ${ }^{[71]}$ and were highly active (S/C ratio up-to 100'000).<smiles>CC/C(C=O)=C\CC1CC=C(C)C1(C)C</smiles>

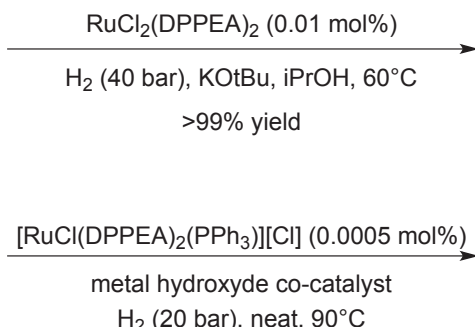

$98 \%$ yield

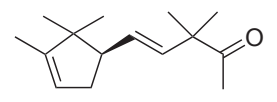

$\mathrm{H}_{2}$ (20 bar), neat, $90^{\circ} \mathrm{C}$
Scheme 23. Synthesis of Sandalwood ingredients by hydrogenation using $\mathrm{Ru}(\mathrm{II})$-complex.

\section{$\operatorname{Dartanol}^{\circledR}(62)$}

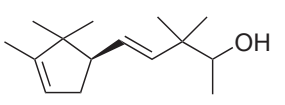

Polysantol $^{\circledR}(63)$ 


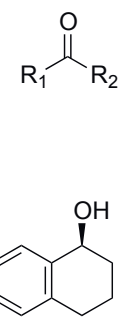

$95 \%$ ee

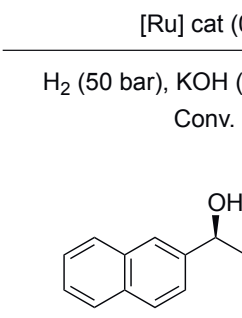

$83 \%$ ee
$\stackrel{\mathrm{OH}}{\stackrel{\mathrm{H}}{\mathrm{R}_{1}}}$<smiles>CC1=CC(C)(C)CC[C@H]1O</smiles>

$95 \%$ ee

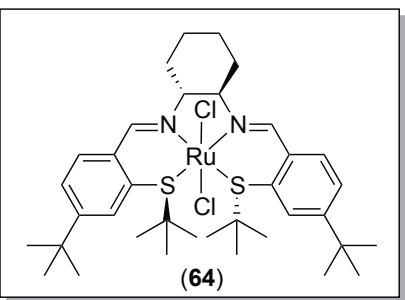

$90 \%$ ee<smiles>CC(O)C1=CCCCC1</smiles>

Scheme 24. $\mathrm{Ru}(\mathrm{II})$ complex 64 with tetradentate amino-thio ether ligand for $\mathrm{C}=\mathrm{O}$ hydrogenation.

\subsubsection{Hydrogenation of Esters ${ }^{[73]}$}

For a long time, ester functional groups remained the most difficult to reduce with dihydrogen and a metal catalyst. ${ }^{[74,75]}$ Internally, the application of Ru catalysts was extended to the hydrogenation of esters based on the initial work by Milstein using the pyridinederived Ru-complex 66 (Scheme 26). ${ }^{[76]}$ It was soon realized that Ru-complexes bearing amino-phosphine ligands, such as complex 67, were highly active in ester reduction under hydrogen (Scheme 26). ${ }^{[73]}$

One key feature is that the Firmenich complex 67 was chemoselective with regards to non-conjugated and non-terminal $\mathrm{C}=\mathrm{C}$ double bonds under conditions where the esters were reduced with $\mathrm{H}_{2}$ (Scheme 27). [73d]
This was a tremendous breakthrough and paved the way to a truly waste-free and green replacement of lithium aluminum hydride reducing agents. Indeed, a reduction of the $E$-factor by a factor of $c a .3 x$ could be expected if the side alcohol formed is not recycled, as opposed to a reduction by a factor of $10^{\prime} 000 \mathrm{x}$ if the by-product alcohol formed is recycled (Scheme 28).

\section{Conclusion}

As of today in 2019, more than 50 years after Wilke's cyclododecatriene synthesis and 85 years after Ruzicka's Muscone synthesis, the field of catalysis continues to reinvent itself and will continue to gain importance within the F\&F industry and beyond. Indeed, the discovery of new perfumery ingredients and the need
Scheme 25. Base-free hydrogenation of aldehydes catalyzed by

$\mathrm{Ru}($ II)-bis-carboxylate complexes (65).

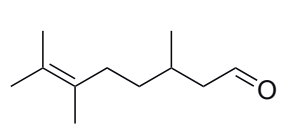

[Ru]cat (0.001 mol\%)

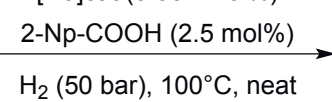<smiles>CC(C)=C(C)CCC(C)CCO</smiles>

Conv. $>99 \%$ Sel. $>99 \%$

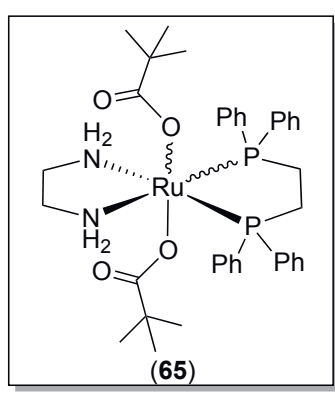

Scheme 26. Comparative examples of esters hydrogenation catalyzed by Ru-complexes 66 and 67.
Milstein Ru-catalyzed ester hydrogenation (2006):
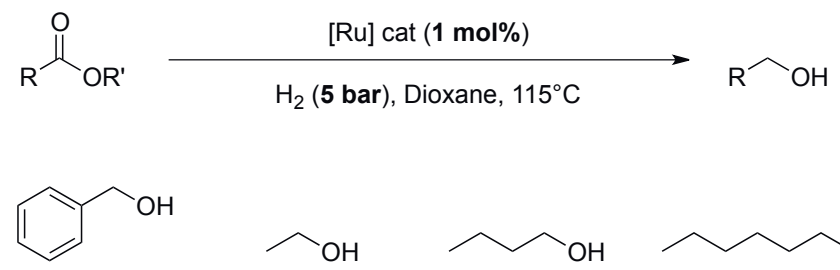

$96 \%$ yield

$86 \%$ yield

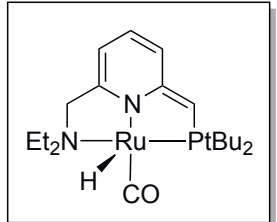

(66)

Firmenich Ru-catalyzed ester hydrogenation (2007):

$$
\mathrm{R}_{\mathrm{OMe}}^{\stackrel{[\mathrm{Ru}] \mathrm{cat}(0.05 \mathrm{~mol} \%)}{\mathrm{H}_{2}(\mathbf{5 0} \text { bar }), \mathrm{NaOMe}(5 \mathrm{~mol} \%), \mathrm{THF}, 100^{\circ} \mathrm{C}}} \mathrm{R}_{\mathrm{OH}}
$$

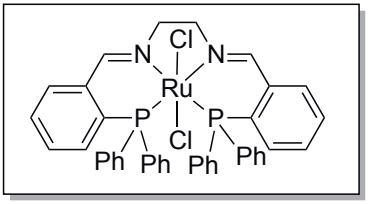

(67)<smiles>OCc1ccccc1</smiles>

$97 \%$ yield<smiles>OCCCc1ccccc1</smiles>

$90 \%$ yield<smiles>OCC1CCCCC1</smiles>

$89 \%$ yield<smiles>CCCCCCCCO</smiles> 


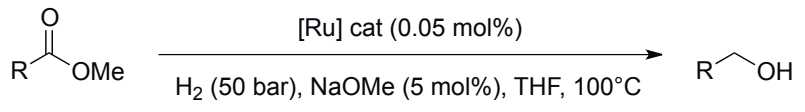

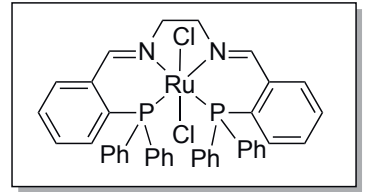

(67)

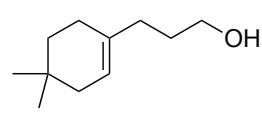

$95 \%$ yield sel. > 98:2<smiles>CC(C)=CCCC(C)CCO</smiles>

$94 \%$ yield sel. 99:1
Scheme 27. Chemo-selective hydrogenation of esters with Rucomplex 67.
$90 \%$ yield sel. 98:2
93\% yield sel. 99:1 to produce existing ingredients in a safer and environmentally benign way will push the F\&F industry towards ever greener industrial processes (Fig. 4). This push will entail the continuous implementation of catalytic reactions in order to reduce waste, solvent and energy. More recently these catalysts are also based on base metals (e.g. Fe, Mn, Co $)^{[77,78]}$ instead of noble metals (e.g. Rh, $\mathrm{Ru}, \mathrm{Pd}, \mathrm{Ir}$ ) which are becoming increasingly difficult to source due to their low abundance and expense. Within Firmenich, some examples of catalytic processes using base metals have already been achieved and have been shown herein.

\section{Acknowledgements}

The author would like to warmly thank Valentin Rautenstrauch for historical comments and Christian Chapuis, Francesco Santoro, Maud Reiter, Gilles Oddon, Elodie Brun and Alec Birkbeck for input and correction of this manuscript.

Received: July 19, 2019

[1] P. T. Anastas, J. C. Warner, 'Green Chemistry: Theory and Practice', Oxford University Press, 1998, p. 30.

[2] Firmenich \& Cie, Patent No. 773.651, 1935.

[3] For reviews on perfumery ingredients, see: a) G. Fráter, J. A. Bajgrowicz, P. Kraft, Tetrahedron 1998, 54, 7633; b) P. Kraft, J. A. Bajgrowicz, C. Denis, G. Fráter, Angew. Chem. Int. Ed. 2000, 39, 2980.
[4] Firmenich, Performance and Sustainability Report 2018

[5] a) H. Mimoun, Chimia 1996, 50, 620; b) C. Chapuis, D. Jacoby, Appl. Catal. A: Gen. 2001, 221, 93; c) L. Saudan, Acc. Chem. Res. 2007, 40, 1309.

[6] a) V. Rautenstrauch, J. Org. Chem. 1984, 49, 950; b) V. Rautenstrauch, EP 0110142, Firmenich SA, 1983. c) V. Rautenstrauch, Tetrahedron Lett. 1984, 25, 3845; d) V. Rautenstrauch, U. Burger, P. Wirthner, Chimia 1985, 39, 225; e) V. Rautenstrauch, Chimia 1985, 39, 227.

[7] H. Strickler, J. B. Davis, G. Ohloff, Helv. Chim. Acta 1976, 59, 1328.

[8] a) E. Demole, E. Lederer, CH 382731, Firmenich SA, 1960; b) E. Demole, E. Lederer, D. Mercier, Helv. Chim. Acta 1962, 65, 685.

[9] a) K. Biemann, G. Büchi, B. H. Walker, J. Am. Chem. Soc. 1957, 79, 5558; b) G. Ohloff, J. Becker, K. H. Schulte-Elte, Helv. Chim. Acta 1967, 70, 705; c) A. Eschenmoser, D. Felix, G. Ohloff, Helv. Chim. Acta 1967, 70, 708; d) D. Felix, J. Schreiber, G. Ohloff, A. Eschenmoser, Helv. Chim. Acta 1971, 54, 2896; e) C. Fehr, G. Ohloff, G. Büchi, Helv. Chim. Acta 1979, 62, 2655.

[10] X. Shi, D. J. Gorin, F. D. Toste, J. Am. Chem. Soc. 2005, 127, 5802.

[11] a) C. Fehr, J. Galindo, Angew. Chem. Int. Ed. 2006, 45, 2901; b) C. Fehr, B. Winter, I. Magpantay, Chem. Eur. J. 2009, 15, 9773; c) see also: A. Fürstner, P. Hannen, Chem. Eur. J. 2006, 12, 3006.

[12] For copper-catalyzed cycloisomerization, see a) C. Fehr, I. Farris, H. Sommer, Org. Lett. 2006, 8, 1839; b) C. Fehr, M. Vuagnoux, A. Buzas, J. Arpagaus, H. Sommer, Chem. Eur. J. 2011, 17, 6214; c) C. Fehr, Synlett 2012, 23, 990.

[13] For copper-catalyzed cyclization-fragmentation, see a) C. Fehr, I. Magpantay, J. Arpagaus, X. Marquet, M. Vuagnoux, Angew. Chem. Int. 2009, 48, 7221; b) C. Fehr, M. Vuagnoux, H. Sommer, Chem. Eur. J. 2011, 17, 3832; c) C. Fehr, M. Vuagnoux, EP 2008/104028, Firmenich SA, 2008.

[14] a) F. Vanasek, V. Herout, F. Sorm, Collect. Czech. Chem. Commun. 1960, 56, 919; b) Y. Ohta, K. Ohara, Y. Hirose, Tetrahedron Lett. 1968, 9, 4181.

[15] For reviews on Au(I/II)- and Pt(II)-catalyzed reactions, see: a) A. Fürstner, Acc. Chem. Res. 2014, 47, 925; b) A. S. K. Hashmi, Acc. Chem. Res. 2014, 47, 864; c) A. Fürstner, P. W. Davies, Angew. Chem. Int. Ed. 2007, 46, 3410.

$\mathrm{R}_{\mathrm{OR}^{\prime}} \stackrel{\text { 1) } \mathrm{LiAlH}_{4}}{\text { 2) work-up }} \underset{\mathrm{R}}{\mathrm{O}} \widehat{\mathrm{OH}}+\mathrm{R}_{\text {(desired) }} \mathrm{OH}+$ Waste as salts $\quad$ E factor ca. 1000

Catalytic reduction with $\mathrm{H}_{2}$

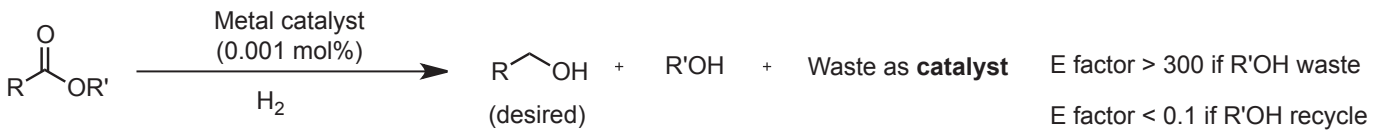

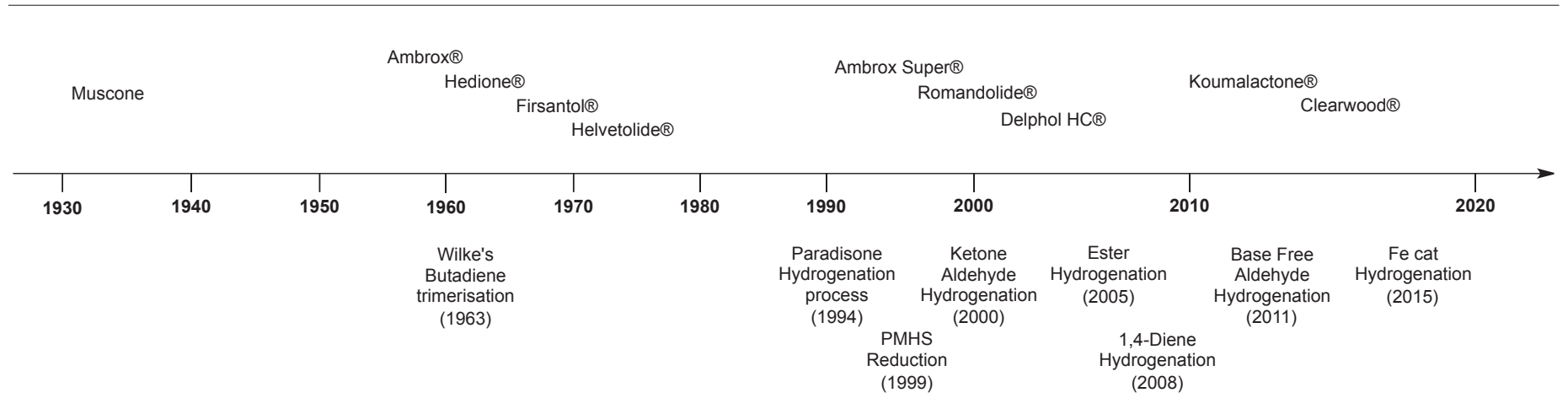

Fig. 4. Some milestones over the past 85 years. 
[16] For a review on $\beta$-Santalol synthesis, see: A. A. Birkbeck, Chimia 2017, 71, 823

[17] a) C. Chapuis, WO 2012/EP52111, Firmenich SA, 2012; b) C. Chapuis, D. Skuy, J.-Y. de Saint Laumer, R. Brauchli, Chem \& Biodiv. 2014, 11, 1470.

[18] a) A. A. Birkbeck, X. Marquet, P. Millet, H. Pamingle, Eur. J. Org. Chem 2014, 7582; b) A. A. Birkbeck, WO 2012/EP62614, Firmenich SA, 2012.

[19] a) P. A. Christenson, B. J. Willis, J. Org. Chem. 1979, 44, 2012; b) P. A. Christenson, B. J. Willis, J. Org. Chem. 1980, 45, 3068.

[20] J. M. Gaudin, Tetrahedron Lett. 1991, 32, 6113.

[21] For the Pd(II)-catalyzed acetoxylation of cycloalkenes, see: H. Mimoun, EP 0685450, Firmenich SA, 1995.

[22] a) K. H. Schulte-Elte, A. Hauser, G. Ohloff, Helv. Chim. Acta 1979, 62, 2673 ; b) V. Rautenstrauch, R. L. Snowden, S. M. Linder, Helv. Chim. Acta 1990, $73,896$.

[23] For a review on the synthesis of macrocyclic musks, see: A. S. Williams, Synthesis 1999, 1707.

[24] L. Ruzicka, M. Stoll, Helv. Chim. Acta 1934, 17, 1308.

[25] a) G. Ohloff, W. Giersch, CH 577445, Firmenich SA, 1973; b) For the synthesis of cyclododecatriene see ref. [29].

[26] a) O. Knopff, J. Kuhne, C. Fehr, Angew. Chemie. Int. Ed. 2007, 46, 1307; b) O. Knopff, WO 2005/077875, Firmenich, SA, 2005; c) O. Knopff, C Fehr, J. Galindo, WO 2007/010483, Firmenich, SA, 2007; d) O. Knopff, WO 2009/095804, Firmenich SA, 2009

[27] D. Felix, J. Schreiber, G. Ohloff, A. Eschenmoser, Helv. Chim. Acta 1971, 54, 2896; b) C. Fehr, G. Ohloff, G. Büchi, Helv. Chim. Acta 1979, 62, 2655.

[28] G. Ohloff, K. H. Schulte-Elte, US 3723478, Firmenich SA, 1966.

[29] G. Wilke, Angew. Chem. Int. Ed. 1963, 2, 105.

[30] Trimofix ${ }^{\circledR}$ is commercialized by IFF (International Flavors and Fragrance) and is characterized by a powerful, diffusive, amber, woody note with vetivert and smoky, tobacco nuances. Slight musky undertone.

[31] C. Chapuis, D. Skuy, C. A. Richard, Helv. Chim. Acta 2019, DOI: 10.1002/ hlca.201900097.

[32] For the direct carbonylation of allylic potassium alkoxide without catalyst, see: a) V. Rautenstrauch, EP 0222145, Firmenich SA, 1986; b) V. Rautenstrauch, Helv. Chim. Acta 1987, 70, 593.

[33] Valentin Rautenstrauch, personal communication.

[34] M. Stoll. M. Hinder, Helv. Chim. Acta 1950, 33, 1251.

[35] S.-I. Murahashi, I. Imada, K. J. Nishimura, Chem. Soc. Chem. Commun 1988, 1578.

[36] J. Currie, A. Charpilloz, V. Rautenstrauch, 1991-1992, unpublished results.

[37] a) V. Rautenstrauch, P. Mégard, B. Gamper, B. Bourdin, E. Walther, G Bernardinelli, Helv. Chim. Acta 1989, 72, 811; b) V. Rautenstrauch, P. Mégard, J. Conesa, W. Küster, Angew. Chem. Int. Ed. 1990, 29, 1413; c) V. Rautenstrauch, W. Keim, CH 681224, Firmenich SA, 1990.

[38] For a review on the synthesis of Hedione $₫$ and methyl jasmonate, see: C. Chapuis, Helv. Chim. Acta 2012, 95, 1479.

[39] a) J.-M. Gaudin, C. Morel, Tetrahedron Lett. 1990, 31, 5749; b) C. Chapuis, Tetrahedron Lett. 1992, 33, 2461

[40] a) C. Chapuis, M. Barthe, EP 0949241, Firmenich SA, 1998; b) C. Chapuis, EP 1060793, Firmenich SA, 1999; c) C. Chapuis, M. Barthe, J.-Y. de Saint Laumer, Helv. Chim. Acta 2001, 84, 230; d) C. Chapuis, Helv. Chim. Acta 2014, 97, 197.

[41] K. Tani, T. Yamagata, S. Akutagawa, H. Kumobayashi, T. Taketomi, H. Takaya, A. Miyashita, R. Noyori, S. Otsuka, J. Am. Chem. Soc. 1984, 106, 5208.

[42] W. Tang, X. Zhang, Chem. Rev. 2003, 103, 3029.

[43] a) C. Fehr, I. Farris, Angew. Chem. Int. Ed. 2006, 45, 6904; b) C. Fehr, I. Magpantay, L. Saudan, H. Sommer, Eur. J. Org. Chem. 2010, 6153; c) C. Chapuis, P. A. Blanc, EP 694 520, Firmenich SA, 1996.

[44] F. Bouachir, B. Chaudret, F. Dahan, F. Agbossou, I. Tkatchenko, Organometallics 1991, 10, 455.

[45] K. H. Schulte-Elte, H. Strickler, F. Gautschi, W. Pickenhagen, M. Gadola, J. Limacher, B. L. Müller, F. Wuffli, G. Ohloff, Liebigs Ann. Chem. 1975, 484

[46] R. Naef, R. Decorzant, Tetrahedron 1986, 42, 3245.

[47] C. Fehr, J. Galindo, Helv. Chim. Acta 1986, 69, 228

[48] C. Fehr, Angew. Chem. Int. Ed. 1996, 35, 2566.

[49] K. H. Schulte-Elte, B. Müller, H. Pamingle, EP 155 591, Firmenich SA, 1984.

[50] J. M. Reuter, R. G. Salomon, J. Org. Chem. 1977, 42, 3360.

[51] K. H. Schulte-Elte, CH 610580, Firmenich SA, 1976.

[52] For a review on photoredox catalysis, see: C. R. J. Stephenson, T. P. Yoon, D. W. C. MacMillan, in 'Visible Light Photocatalysis in Organic Chemistry', Wiley-VCH, 2018

[53] G. Ohloff, E. Klein, G. O. Schenck, Angew. Chem. 1961, 73, 578.

[54] For reviews on ruthenium-catalyzed hydrogenations at Firmenich, see: a) ref. [5c]. b) P. Dupau, Top. Organomet. Chem. 2012, 42, 47; c) P. Dupau, Helv. Chim. Acta 2018, 101, e1800144.
[55] According to V. Rautenstrauch, who was one of the seminal players in this blooming field, this project was the most successful and enriching experience of his career. This involved many people inside Firmenich as well as outside through intense collaborations with academic groups.

[56] a) V. Rautenstrauch, J.-J. Riedhauser, WO 1996/00206, Firmenich SA, 1994; b) D. A. Dobbs, K. P. M. Vanhessche, E. Brazi, V. Rautenstrauch, J.-Y. Lenoir, J.-P. Genêt, J. Wiles, S. H. Bergens, Angew. Chem. Int. Ed. 2000, 39 , 1992; c) J. A. Wiles, S. H. Bergens, K. P. M. Vanhessche, D. A. Dobbs, V. Rautenstrauch, Angew. Chem. Int. Ed. 2001, 40, 914; d) V. Rautenstrauch, Org. Process Res. Dev. 2012, 16, 1185.

[57] C. Fehr, J. Galindo, Angew. Chem. Int. Ed. 2000, 39, 569.

[58] For a review of the synthesis of $\mathbf{5 9}$, see ref. [38].

[59] R. Noyori, Adv. Synth. Catal. 2003, 345, 15.

[60] a) P. Dupau, L. Bonomo, WO 2008/120175, Firmenich SA, 2007; b) C. Fehr, I. Magpantay, M. Vuagnoux, P. Dupau, Chem. Eur. J. 2011, 17, 1257.

[61] Leaf Alcohol is commercialized by Zeon Corporation.

[62] a) S. Steines, U. Engelert, B. Driessen-Hölscher, Chem. Commun. 2000, 217; b) J. Kirchhoff, G. Fries, B. Driessen-Hoelscher, W. Kalz, M. Nobis, EP 1394170, Degussa AG, 2004.

[63] For a seminal work done at Firmenich on zinc-catalyzed hydrosilylation of $\mathrm{C}=\mathrm{O}$ functional groups on industrial scale, see: a) $\mathrm{H}$. Mimoun, J. Org. Chem. 1999, 64, 2582; b) H. Mimoun, J.-Y. de Saint Laumer, L. Giannini, R. Scopelliti, C. Floriani, J. Am. Chem. Soc. 1999, 121, 6158.

[64] For the hydrogenation with ruthenium complexes bearing amino-phopshine ligands see: a) V. Rautenstrauch, R. Churlaud, R. H. Morris, K. AbdurRashid, WO 2002/40155, Firmenich SA, 2000; b) V. Rautenstrauch, R. Challand, R. Churlaud, R. H. Morris, K. Abdur-Rashid, E. Brazi, H. Mimoun, WO 2002/22526, Firmenich SA, 2000; c) V. Rautenstrauch, X. Hoang-Cong, R. Churlaud, K. Abdur-Rashid, R. H. Morris, Chem. Eur. J. 2003, 9,4954

[65] For the hydrogenation with ruthenium complexes bearing amino-thioether ligand see: a) F. Santoro, L. Saudan, C. Saudan, WO 2012/084810, Firmenich SA, 2010; b) R. Patchett, I. Magpantay, L. Saudan, C. Shotes, A. Mezzetti, F. Santoro, Angew. Chem. Int. Ed. 2013, 52, 10352.

[66] For the hydrogenation with ruthenium complexes bearing (diamine-PN) ligand see: L. Saudan, C. Saudan, WO 2010/061350, Firmenich SA, 2008

[67] For the hydrogenation with ruthenium complexes bearing (diamine-PO) ligand see: L. Saudan, C. Saudan, WO 2010/038209, Firmenich SA, 2008.

[68] a) T. Ohkuma, H. Ooka, T. Ikariya, R. Noyori, J. Am. Chem. Soc. 1995, 117, 10417; b) T. Ohkuma, H. Ooka, S. Hashiguchi, T. Ikariya, R. Noyori, J. Am. Chem. Soc. 1995, 117, 2675.

[69] For the structure elucidation of the ruthenium(II)-DPPEA complex, see ref. [54b]

[70] a) P. Dupau, L. Bonomo, L. Kermorvan, Angew. Chem. Int. Ed. 2013, 52, 11347; b) P. Dupau, L. Bonomo, L. Kermorvan, WO 2013/050297, Firmenich SA, 2011.

[71] For the synthesis of $\mathrm{Ru}(\mathrm{PP})(\mathrm{NN})(\mathrm{RCOO})_{2}$ see: L. Bonomo, P. Dupau, S. Bonnaudet, WO 2011/145032, Firmenich SA, 2010.

[72] T. Ohkuma, M. Koizumi, K. Muñiz, G. Hilt, G. Kabuto, R. Noyori, J. Am. Chem. Soc. 2002, 124, 6508.

[73] a) L. Saudan, P. Dupau, J.-J. Riedhauser, P. Wyss, WO 2006/106483, Firmenich SA, 2005; b) L. Saudan, P. Dupau, J.-J. Riedhauser, P. Wyss, WO 2006/106484, Firmenich SA, 2005; c) L. Saudan, C. Saudan, WO 2008/065588, Firmenich SA, 2006; d) L. A. Saudan, C. M. Saudan, C. Debieux, P. Wyss, Angew. Chem. Int. Ed. 2007, 46, 7473.

[74] H. T. Teunissen, C. J. Elsevier, Chem. Commun. 1998, 1367

[75] For reviews on the hydrogenation of esters and other carboxylic derivatives see: a) P. A. Dub, T. Ikariya, ACS Catal. 2012, 2, 1718; b) L. A. Saudan, in 'Applied Homogeneous Catalysis with Organometallic Compounds: A Comprehensive Handbook in Three Volumes', Eds: B. Cornils, W. A Herrmann, M. Beller, R. Paciello, Wiley-VCH, Weinheim, 2017; c) L. A Saudan, in 'Sustainable Catalysis, Eds: P. J. Dunn, K. K. Hii, M. J. Krische, M. T. Williams, Wiley \& Sons, New Jersey, 2013, pp. 37-61; d) M. L. Clark, G. J. Roff, in 'The Handbook of Homogeneous Hydrogenation', Eds: J. G. de Vries, C. J. Elsevier, Wiley-VCH, Weinheim, 2007, pp. 313-454; e) M. Ito, T. Ikariya, Chem. Commun. 2007, 5134.

[76] J. Zhang, G. Leitus, Y. Ben-David, D. Milstein, Angew. Chem. Int. Ed. 2006, $45,1113$.

[77] For reviews on hydrogenation using base metal complexes, see: a) P. Dupau, M.-L. Tran Do, S. Gaillard, J.-L. Renaud, Angew. Chem. Int. Ed. 2014, 53, 13004.

[78] a) J. Quintaine, L. Saudan, WO 2015/091158, Firmenich SA, 2013; b) L. Saudan, J. Praz, WO 2016/202925, Firmenich SA, 2015. 